\title{
Assessment of long-term effects of the macroalgae Ulva ohnoi included in diets on Senegalese sole (Solea senegalensis) fillet quality
}

\author{
M.I. Sáez ${ }^{\mathrm{a}}$, A. Vizcaíno ${ }^{\mathrm{a}}$, A. Galafat ${ }^{\mathrm{a}}$, V. Anguís ${ }^{\mathrm{b}}$, C. Fernández-Díaz ${ }^{\mathrm{b}}$, M.C. Balebona ${ }^{\mathrm{c}}$, \\ F.J. Alarcón ${ }^{\mathrm{a}}$, T.F. Martínez ${ }^{\mathrm{a}, *}$ \\ ${ }^{a}$ Departamento de Biología y Geología, Campus de Excelencia Internacional CEIMAR, Universidad de Almería, 04120 Almería, (Spain) \\ b IFAPA “El Toruño", Junta de Andalucía, 11500 - El Puerto de Santa María, Cádiz, (Spain) \\ ${ }^{\mathrm{c}}$ Facultad de Ciencias, Universidad de Málaga, 29071 Málaga, (Spain)
}

\section{A R T I C L E I N F O}

\section{Keywords:}

Fish quality

Frozen fish

Functional additive

Lipid oxidation

Macroalgae

Solea senegalensis

Ulva ohnoi

\begin{abstract}
A B S T R A C T
Macroalgae are a promising source of a vast variety of bioactive compounds with potential interest in aquaculture. In addition to their sustainable and renewable nature, numerous evidences have been reported pointing to positive effects on fish growth, nutrient utilization, and disease resistance. Nevertheless, the effects on fish quality objective parameters have been scarcely explored. In this study we assessed the influence of Ulva ohnoi included at low level (5\%) in a diet for Senegalese sole (Solea senegalensis) on several quality attributes of fish (proximate analysis, texture profile analysis, lipid oxidation, fatty acid profile, $\mathrm{pH}$, water holding capacity, and colour parameters). A 270-d feeding trial was carried out, in which juvenile animals were fed with an Ulvaenriched diet only for $90 \mathrm{~d}$ out of the total 270-d study. This enabled to evaluate whether the possible effects on fish were transitory or persistent at the end of the assay. Besides modest effects on fish growth at early stages, the differences attributable to Ulva supplementation were mostly focused on the lipid fraction, texture, and colour parameters. Thus, Ulva diet reduced muscle total lipid content and favoured muscle selective retention of $\mathrm{n}-3$ polyunsaturated fatty acids (PUFA), not least eicosapentaenoic acid (EPA) and docosahexaenoic (DHA) acid, and also diminished lipid oxidation, especially after a period of frozen storage. In terms of consumers' acceptability, seaweed supplementation impacted favourably on fillet texture and colour attributes, namely by increasing lightness $\left(L^{*}\right)$ and yellowness $\left(b^{*}\right)$, whilst reducing redness $\left(a^{*}\right)$. These results are particularly remarkable taking into account that low inclusion level was considered (5\%), and above all, that Ulva supplementation was interrupted after $90 \mathrm{~d}$, but the effects mentioned persisted at least up to $270 \mathrm{~d}$. These deferred long-term effects might well be of practical interest when it comes to modifying quality attributes of edible fish.
\end{abstract}

\section{Introduction}

Macroalgae have been proposed as an alternative and renewable feeding resource for a sustainable aquaculture [1]. Thus, several studies have reported positive effects of seaweed-enriched aquafeeds on fish growth, nutrient utilization [2,3], resistance to infectious diseases [4], as well as on objective quality parameters in different fish species [5-7].

However, several issues hinder the utilization of macroalgae as an ingredient at industrial scale, not least those related to the drying process, a necessary but costly step prior to any practical application in feed manufacturing [1]. As a result, the interest raised for macroalgae in the last years is turning from their role as a main quantitative ingredient, towards their potential as a natural source of qualitative bioactive compounds. Indeed, seaweeds contain potentially nutraceutical or functional substances, such as polysaccharides, fibre, pigments, polyphenols and vitamins [8,9]. Thereby, the practical utilization of macroalgae in aquafeeds is nowadays more focused on their interest as additive at low inclusion levels, than to their consideration as main ingredient $[1,7,10]$.

Ulva sp. is one of the most widely assessed genera of edible macroalgae in aquaculture feeding trials, owing to its richness either in identified [11,12] or in still unknown bioactive compounds [13]. As mentioned, a vast array of benefits regarding growth performance and health strengthening has been reported for different fish species, but potential effects on fish quality have been studied less extensively [14].

The interest of macroalgae as feed additive at early stages of the fish production cycle (namely pre-ongrowing and ongrowing periods)

\footnotetext{
* Corresponding author at: Departamento de Biología y Geología, Universidad de Almería, 04120 Almería, (Spain).

E-mail address: tomas@ual.es (T.F. Martínez).
} 
probably relies on their potential effects on fish physiology and disease resistance $[7,15]$. Nevertheless, when it comes to final stages, the ability to influence sensory and quality attributes of commercial fish is the most appreciable characteristic of any potential additive, given that such attributes are modifiable through dietary changes $[16,17]$. Although this specific aspect has been widely reported for many aquacultured species, scarce research is available on the effects of macroalgae-including diets on fillet quality attributes.

Senegalese sole (Solea senegalensis) is emerging as a potential candidate when it comes to diversifying the aquacultured fish species in Southern Europe [18], currently too dependent on European sea bream (Sparus aurata) and sea bass (Dicentrarchus labrax), two species that show clear signs of exhaustion in terms of profitability. This flatfish is nowadays farmed at modest but growing levels, fostered by its high market value. After some industrial processing, flatfish species are also commercialized as frozen, especially owing to their leanness, since high lipid content is considered a major constrain for frozen storage. When properly carried out, current freezing technology enables fish preservation over long storage periods [19] whilst keeping microbial, sensorial and nutritional attributes almost indistinguishable from fresh fish [20,21]. In this regard, the suitability of Senegalese sole for freezing is not an exception among flatfish species.

Although plenty of literature regarding reproduction and nutrition is available, scarce studies have assessed the influence of diets on $S$. senegalensis fillet objective quality parameters [22]. In this context, this piece of research explores not only whether the inclusion of Ulva ohnoi at low dietary level could influence objective quality parameters of $S$. senegalensis, but also whether interrupted feeding of juvenile fish with such experimental diet could yield long-term effects on those attributes in commercial size fish, and specially, after a period of frozen storage. In this regard, it is hypothesized that a persistent effect might occur, whereby nutritional strategies involving macroalgae at early growing stages could yield deferred effects on fillet quality parameters of animals reaching their commercial size thereafter.

\section{Materials and methods}

\subsection{Macroalgae and experimental diets}

Ulva ohnoi (Hiraoka and Shimada strain UOHN120810) was isolated from the outlet channel IFAPA El Toruño (Cádiz, Spain) facilities, and maintained in culture. To obtain the biomass needed for preparation of Ulva diet, stock cultures were up-scaled to $1000 \mathrm{~L}$ tanks. Ulva biomass $\left(1 \mathrm{~kg} \mathrm{~m}^{-3}\right)$ was cultured under natural photoperiod light in filtered $(0.2 \mu \mathrm{m})$ natural seawater enriched with $\mathrm{f} / 2$ medium [23]. After two weeks, algae were harvested, rinsed with tap water, freeze-dried, and kept in a dry place until further utilization in the elaboration of the experimental diets.

Two isonitrogenous (55\% on dry weight basis) and isolipidic ( $12 \%$ on dry weight) experimental diets (Table 1) were elaborated by LifeBioencapsulation S.L. (Spin-off, Universidad de Almería, Spain). U-5 diet was formulated so as to include $5 \%(\mathrm{w} / \mathrm{w})$ dry $U$. ohnoi biomass. An algae-free diet was used as control (C). Feed ingredients were finely ground and mixed together, and then water was added to the mixture to make up homogeneous dough in a vertical helix ribbon mixer (Sammic BM-10, Sammic, Azpeitia, Spain). The dough was passed through a single screw laboratory extruder (Miltenz 51SP, JSConwell Ltd., New Zealand) to obtain pellets ranging from 1.1 to $5 \mathrm{~mm}$ diameter, according to the age of fish. The extruder barrel consisted of four sections and the temperature profile in each section (from inlet to outlet) was $100{ }^{\circ} \mathrm{C}, 95^{\circ} \mathrm{C}, 90^{\circ} \mathrm{C}$ and $85^{\circ} \mathrm{C}$, respectively. The resulting pellets were dried (forced ventilation) at room temperature for $24 \mathrm{~h}$, and stored in sealed plastic bags at $-20^{\circ} \mathrm{C}$ until use.
Table 1

Ingredient composition of the experimental diets used in the feeding trial.

\begin{tabular}{|c|c|c|}
\hline Ingredients ( $\mathrm{g} \mathrm{kg}^{-1}$ dry weight) & $\mathrm{C}$ & U-5 \\
\hline Fishmeal LT ${ }^{\mathrm{a}}$ & 674 & 660 \\
\hline Ulva meal & - & 50 \\
\hline Squid meal ${ }^{\mathrm{b}}$ & 50 & 50 \\
\hline Fish protein hydrolysate $^{c}$ & 50 & 50 \\
\hline Krill meal $^{\mathrm{b}}$ & 10 & 10 \\
\hline Shrimp meal ${ }^{\mathrm{b}}$ & 10 & 10 \\
\hline Gluten meal $^{\mathrm{b}}$ & 20 & 20 \\
\hline Soybean protein concentrate ${ }^{\mathrm{d}}$ & 20 & 20 \\
\hline Fish oil & 30 & 29 \\
\hline Soybean lecithin & 20 & 20 \\
\hline Maltodextrin & 46 & 11 \\
\hline Choline chloride $^{\mathrm{e}}$ & 10 & 10 \\
\hline Vitamin and mineral premix ${ }^{f}$ & 30 & 30 \\
\hline Guar gum ${ }^{b}$ & 15 & 15 \\
\hline Alginate $^{\mathrm{b}}$ & 15 & 15 \\
\hline Crude protein (\%) & 55.2 & 55.0 \\
\hline Crude lipid (\%) & 12.4 & 12.0 \\
\hline Ash (\%) & 12.8 & 13.1 \\
\hline Fibre (\%) & 3.0 & 3.3 \\
\hline
\end{tabular}

Dietary treatments are C: control diet; U-5: 5\% U. ohnoi meal inclusion.

a (69.4\% crude protein, $12.3 \%$ crude lipid). Norsildemel (Bergen. Norway).

b LifeBioencapsulation (Almería, Spain).

c ( $81 \%$ crude protein. $8.8 \%$ crude lipid) Sopropeche (France).

d (65\% crude protein. $8 \%$ crude lipid) DSM (France).

e Sigma-Aldrich (Madrid, Spain).

f Mineral and vitamin premix according to Vizcaíno et al. [73].

\subsection{Fish maintenance and experimental design}

Juvenile Senegalese sole (Solea senegalensis) (10.5 $\pm 2.7 \mathrm{~g}$ initial body weight) were obtained from a commercial hatchery (Cupimar S.A., Cádiz, Spain) and transported to the facilities of the IFAPA El Toruño (Cádiz, Spain) research centre. Fish were placed initially in a recirculating aquaculture system $(6 \times 400 \mathrm{~L}$ tanks $)$, consisting of a mechanical filter, a skimmer, ultraviolet light and biofilter. UV-sterilized water at $19.9 \pm 0.7^{\circ} \mathrm{C}$ was provided at $150 \mathrm{~L} \mathrm{~h}^{-1}$. Supplemental aeration was provided in order to maintain dissolved oxygen above $7.0 \mathrm{mgL}^{-1} ; \mathrm{pH}$ was maintained at $7.8 \pm 0.2$, and salinity at $25.7 \pm 1.5 \%$. Photoperiod was fixed on a $12: 12 \mathrm{~h}$ light:dark cycle (150 lx).

Ammonia $\left(<0.1 \mathrm{mg} \mathrm{L}^{-1}\right)$ and nitrite $\left(<0.1 \mathrm{mg} \mathrm{L}^{-1}\right)$ were determined daily at 9:00 a.m.

Prior to the assays, animals were acclimated to the conditions of the experimental facilities for ten days, and fed daily at $2 \%$ body weight ratio with a control diet (C). Then, fish were divided into two groups and stocked at $1.5 \mathrm{~kg} \mathrm{~m}^{-2}$ in 6 tanks ( 2 groups $\times 3$ tanks per group $\times 250$ fish per tank). In the first experimental group (designed as U-5) animals were fed at a rate of $3 \%$ of their body weight with a diet containing $U$. ohnoi $(5 \% \mathrm{w} / \mathrm{w})$ for a 90 -day period. Automatic feeders were used along the trial and fish were fed 4 times a day up to day 90 , and twice per day from this time onwards. For estimating the feed intake, the uneaten feed was carefully collected by siphoning $60 \mathrm{~min}$ after the administration, then dried for $12 \mathrm{~h}$ at $110 \mathrm{C}$, and weighed.

In parallel, a group of animals fed with control diet (C) completed the experimental layout. After 90 days being fed on the experimental diet, feeding with Ulva diet was ceased in U-5 batch, and then both control and U-5 specimens (165 fish per tank) continued for a 180-d additional period, being all fish fed exclusively with control diet without macroalgae supplementation ( $2 \%$ biomass daily), up to the completion of the 270-d feeding trial. During the second period of the feeding trial (from 90 to $270 \mathrm{~d}$ ), fish were placed in $800 \mathrm{~L}$ rectangular tanks $(2 \times 0.8 \times 0.5 \mathrm{~m})$. 


\subsection{Sampling}

Fish weight was measured at 45, 90 and 270 days from the beginning of the feeding trial. At any sampling time withdrawn fish (75 animals at both 45 and $90 \mathrm{~d}$, and 90 animals at day 270) were anesthetized (clove oil overdose, $200 \mathrm{mg} \mathrm{L}^{-1}$ ) and slaughtered (spine severing) in compliance with Directive 2010/63/EU. Immediately, skin colour was recorded, then animals were gutted, and muscle samples were taken for proximate analysis and thiobarbituric acid-reactive substances (TBARS) determinations. The 270-d fish were then filleted, packed in transparent sterile polyethylene bags, and directly stored at $-20{ }^{\circ} \mathrm{C}$ for a total freezing period of 6 months. Thereafter fillets were thawed and muscle samples were withdrawn for fatty acid profile analysis. Thawed fillets were then stored in a cold room $\left(4^{\circ} \mathrm{C} \pm 1{ }^{\circ} \mathrm{C}\right)$ for an additional period of $10 \mathrm{~d}$, with the aim of assessing changes in quality parameters throughout the refrigerated post-thawing shelf life. Samples were extracted from each lot at 1, 3, 5, 8 and 10 days postthawing, and flesh colour parameters, $\mathrm{pH}$, water holding capacity (WHC), texture profile analysis (TPA), and lipid oxidation were determined.

\subsection{Proximate composition and fatty acids analysis}

Proximate analysis (dry matter, ash, and crude protein, $\mathrm{N} \times 6.25$ ) of feeds and muscle samples were determined according to Association of Official Agricultural Chemists (AOAC) [24] procedures. Lipids were extracted following Folch et al. [25] methodology using chloroform/ methanol $(2: 1 \mathrm{v} / \mathrm{v})$ as solvent, and total lipid content was calculated gravimetrically. Fatty acid (FA) profile was determined by gas chromatography following the method described in Rodríguez-Ruiz et al. [26], by means of a gas chromatograph (Hewlett Packard, 4890 Series II, Hewlett Packard Company, Avondale, PA) using a modification of the direct transesterification method described by Lepage and Roy [27] that requires no prior separation of the lipid fraction.

From FA profile of fish muscle, the index of atherogenicity (IA) and the index of thrombogenicity (IT) were calculated according to Senso et al. [28] as follows:

Index of atherogenicity (IA) $=(12: 0+4 * 14: 0+16: 0) /$ $[(n 6+n 3)$ PUFAs $+18: 1+$ other MUFAs $]$; index of thrombogenicity $(\mathrm{IT})=(14: 0+16: 0+18: 0) /$

$[(0.5 * 18: 1)+(0.5 *$ IMUFAs $)+(0.5 * \mathrm{n} 6$-PUFAs $)+(3 * \mathrm{n} 3-$ PUFAs $+(n 3 / n 6)]$, where MUFAs and PUFAs stand for monounsaturated fatty acids and polyunsaturated fatty acids, respectively.

The value of flesh-lipid quality (FLQ) indicates ratio between the sum of eicosapentaenoic acid (EPA, 20:5n3) and docosahexaenoic acid (DHA, 22:6n3), and total lipids, expressed as mg per $100 \mathrm{~g}$ edible flesh.

\subsection{Lipid oxidation}

At 45,90 and 270 days, lipid oxidation was estimated by thiobarbituric acid-reactive substances (TBARS) analysis in fresh muscle. Throughout the 10-d post-thawing cold storage $\left(4^{\circ} \mathrm{C}\right)$ period considered, TBARS were also measured in muscle samples according to the method of Buege and Aust [29]. Samples (2 g each) were homogenized in $4 \mathrm{~mL}$ of $50 \mathrm{mM} \mathrm{NaH} \mathrm{PO}_{4}, 0.1 \%(\mathrm{v} / \mathrm{v})$ Triton X-100 solution. The mixture was centrifuged $\left(10,000 \mathrm{~g}, 20 \mathrm{~min}, 4^{\circ} \mathrm{C}\right)$ and supernatants were mixed in a ratio $1: 5(\mathrm{v} / \mathrm{v})$ with 2-thiobarbituric acid (TBA) reagent $(0.375 \% \mathrm{w} / \mathrm{v}$ TBA, $15 \% \mathrm{w} / \mathrm{v}$ TCA, $0.01 \% \mathrm{w} / \mathrm{v} 2$ 2,6-dibutyl hydroxytoluene (BHT) and $0.25 \mathrm{~N} \mathrm{HCl}$ ). The mixture was heated for $15 \mathrm{~min}$ and then centrifuged $\left(3600 \mathrm{~g}, 10 \mathrm{~min}, 4^{\circ} \mathrm{C}\right)$, and the absorbance of supernatants was measured at $535 \mathrm{~nm}$. The amount of TBARS was expressed as mg of malonyl dialdehyde (MDA) per $\mathrm{kg}$ of muscle after comparing with a MDA standard.

\subsection{Instrumental colour determination}

For all fresh fish samples (45, 90 and $270 \mathrm{~d})$ colour was measured on skin (ocular and blind sides of fillets dorsal portion by $L^{*}, a^{*}$, and $b^{*}$ system [30], using a Minolta Chroma meter CR400 device (Minolta, Osaka, Japan). During post-thawing storage at $4^{\circ} \mathrm{C}$, skin and flesh colour of fillets was also determined at the different sampling times considered (1, 3, 5, 8 and $10 \mathrm{~d}$ post-thawing). The parameter lightness ( $L^{*}$, on a $0-100$ point scale from black to white), redness ( $a^{*}$, assesses the position between red, positive values, and green, negative values), and yellowness $\left(b^{*}\right.$, assesses the position between yellow, positive values, and blue, negative values) were recorded.

\section{7. $p H$ and water holding capacity (WHC)}

Muscle $\mathrm{pH}$ was determined in the anterior part of dorsal muscle by means of a penetration electrode (Crison, model GLP 21; sensitivity $0.01 \mathrm{pH}$ units). Water holding capacity (WHC, expressed as a percentage) was calculated from small cubical pieces $\left(1 \mathrm{~cm}^{3}\right)$ obtained from the anterior part of dorsal muscle as the difference between the initial percentage of water and the percentage of water released after centrifugation, as detailed in Suárez et al. [31].

\subsection{Texture profile analysis (TPA)}

Fillet texture was measured by compression of the dorsal anterior area, above the lateral line of the ocular side of fillets, using a Texture Analyser (TXT2 plus "Stable Mycro System"), equipped with a load cell of $5 \mathrm{kN}$, controlled with Texture Expert Exceed 2.52 software (Stable Micro Systems, Surrey, England).

Muscle samples were subjected to two consecutive cycles of $25 \%$ compression, with $5 \mathrm{~s}$ between cycles, in which a $20-\mathrm{mm}$ cylindrical probe was used for pressing downwards into the fillet at a constant speed of $1 \mathrm{~mm} / \mathrm{s}$. During the tests, fillets were kept on a bed of crushed ice. Textural parameters as hardness (maximum force required to compress the sample), springiness (ability of the sample to recover its original form after removing the deforming force), cohesiveness (extent to which the sample could be deformed prior to rupture), gumminess (force needed to disintegrate a semisolid sample to a steady state of swallowing), chewiness (the work needed to chew a solid sample to reach a steady state of swallowing) and resilience (how well a product fights to regain its original position) were calculated as described by Bourne [32].

\subsection{Statistics}

The effect of the categorical variables "algae" and "storage time", as well as their interactions, were determined for each numeric parameter studied by fitting a generalized lineal statistical model (GLM analysis) that relates measured parameters to predictive factors, using specific software (SPSS 25, IBM Corporation Inc.). Least squares means were tested for differences using Fisher's least significant difference (LSD) procedure. Unless otherwise specified, a significance level of 95\% was considered to indicate statistical differences $(p<0.05)$. When measurements were expressed as a percentage (e.g. water holding capacity), arcsine transformation of their square root was carried out in order to normalize data prior to the statistical analysis.

\section{Results}

\subsection{Growth performance and body composition}

Fish mortality was below $5 \%$ in all tanks. Senegalese sole mean body weight and proximate composition of muscle determined at different sampling times of the feeding trial are shown in Table 2 . After 45 and 90-d, U-5 fish showed significantly lower final body weight 
Table 2

Effects of the dietary inclusion of Ulva ohnoi on growth and muscle composition of Solea senegalensis at 45, 90 and 270 days of the feeding trial.

\begin{tabular}{|c|c|c|c|c|c|c|}
\hline $\begin{array}{l}\text { Time } \\
\text { (days) }\end{array}$ & Diet & $\begin{array}{l}\text { Weight } \\
\text { (g) }\end{array}$ & $\begin{array}{l}\text { Protein } \\
(\%)\end{array}$ & $\begin{array}{l}\text { Lipid } \\
(\%)\end{array}$ & $\begin{array}{l}\text { Ash } \\
(\%)\end{array}$ & $\begin{array}{l}\text { Moisture } \\
(\%)\end{array}$ \\
\hline \multirow[t]{3}{*}{45} & $\mathrm{C}$ & $28.2 \pm 0.8^{b}$ & $17.44 \pm 0.29^{\mathrm{a}}$ & $6.89 \pm 0.72$ & $1.27 \pm 0.03^{\mathrm{a}}$ & $78.80 \pm 0.36$ \\
\hline & U-5 & $24.9 \pm 0.6^{\mathrm{a}}$ & $18.38 \pm 0.21^{\mathrm{b}}$ & $7.80 \pm 0.96$ & $1.39 \pm 0.04^{\mathrm{b}}$ & $78.06 \pm 0.31$ \\
\hline & $p$ & 0.025 & 0.010 & n.s. & 0.010 & 0.054 \\
\hline \multirow[t]{3}{*}{90} & $\mathrm{C}$ & $55.5 \pm 1.2^{\mathrm{b}}$ & $19.95 \pm 0.25$ & $8.14 \pm 0.60$ & $0.96 \pm 0.03$ & $75.83 \pm 0.46$ \\
\hline & U-5 & $50.1 \pm 1.1^{\mathrm{a}}$ & $20.16 \pm 0.72$ & $7.48 \pm 0.98$ & $1.00 \pm 0.09$ & $76.02 \pm 0.57$ \\
\hline & $p$ & 0.039 & n.s. & n.s. & n.s. & n.s. \\
\hline \multirow[t]{3}{*}{270} & $\mathrm{C}$ & $213.3 \pm 25.2$ & $18.82 \pm 0.32$ & $7.48 \pm 0.37^{\mathrm{a}}$ & $1.34 \pm 0.03$ & $75.08 \pm 0.31$ \\
\hline & U-5 & $212.7 \pm 30.3$ & $19.67 \pm 1.08$ & $6.02 \pm 0.08^{\mathrm{b}}$ & $1.28 \pm 0.04$ & $75.33 \pm 0.90$ \\
\hline & $p$ & n.s. & n.s. & 0.015 & n.s. & n.s. \\
\hline
\end{tabular}

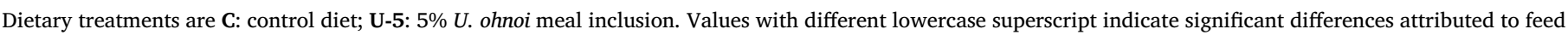

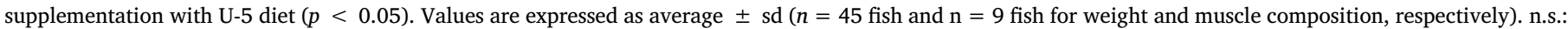
not significant.

compared to control (C) batch. However, these differences between treatments disappeared after 270-d $(p=0.7874)$.

With regard to muscle composition, slight, but not significant, differences in protein and ash contents were observed at any of the sampling times between both experimental groups.

The dietary treatment including $U$. ohnoi yielded no significant differences in muscle total lipid contents at 45 and $90 \mathrm{~d}$ compared to the controls, whereas fish fed with U-5 diet showed significantly lower values for this parameter at the end of the feeding trial.

\subsection{Muscle fatty acids profile}

Polyunsaturated fatty acids (PUFA) were the prevailing fatty acids in fish muscle (Table 3 ) at the end of the feeding trial, irrespectively of the dietary treatment considered (41-45\% of total FAs), followed by saturated fatty acids (SFAs, 27-28\%), and then monounsaturated fatty acids (MUFAs, 21-25\%).

The main effect of U-5 dietary treatment on muscle lipids can be summarized as that PUFA relative content increased significantly (41.2 vs. $45.2 \%$ ), whereas MUFA values decreased, and SFA didn't change (Table 3). Considered individually, palmitic acid (16:0) was the predominant fatty acid in control fish (19.4\%), followed by docosahexaenoic acid (DHA, 22:6n3; 19\%), and oleic acid (18:1n9; 15.9\%). On the other hand, Ulva-fed fish yielded DHA as the most abundant fatty acid in muscle (23.4\%), followed by palmitic acid (19.8\%), and oleic acid (14.6\%). Not only DHA, but also the proportion of eicosapentaenoic acid (EPA, 20:5n3) was significantly higher in U-5 fed fish, this contributing to significant increase in total n-3 highly-unsaturated fatty acids (HUFA). As a result of these changes, Ulva-fed fish showed significantly higher $\mathrm{n} 3 / \mathrm{n} 6$ ratio, lipid quality index (FLQ), as well as lower index of atherogenicity (IA).

\subsection{Muscle lipid oxidation}

Lipid oxidation measurements in fresh muscle (Table 4) indicated no differences attributable to the dietary treatment at any of the sampling times considered throughout the feeding trial. On the contrary, differences were observed for TBARS during the post-thawing cold storage (Fig. 1) of 270-d fish fillets. In this regard, lipid oxidation was clearly dependant on storage time in both experimental groups, as evidenced by the significant increase of this parameter from the beginning to the end of the cold storage period $(p<0.001)$. However, although the most contributing factor to TBARS concentration was storage time, $U$. ohnoi decreased significantly $(p<0.001)$ fillet lipid oxidation at any sampling time, compared to $\mathrm{C}$ batch.

\subsection{Instrumental colour determination}

With regard to instrumental colour (Table 4), no influence of the dietary treatment was observed in any of the colour parameters studied on fillets obtained from the blind side of fresh fish after 45, 90, and 270$\mathrm{d}$ of feeding trial (data not shown).

On the other hand, fillets from the ocular (pigmented) side showed significant differences at any sampling time considered for the parameters $L^{*}, a^{*}$ and $b^{*}$ attributable to the inclusion of $U$. ohnoi in diets. Roughly, U-5 fillets showed higher lightness $\left(L^{*}\right)$ and yellowness $\left(b^{*}\right)$, but lower redness ( $\left.a^{*}\right)$ than control fillets, irrespectively of the sampling time considered.

With regard to post-thawing cold storage of fillets (Fig. 2), roughly, the differences mentioned were kept throughout the complete period $(10 \mathrm{~d}) . L^{*}$ decreased significantly in control specimens $(p<0.001)$ throughout the 10-d cold storage, whereas this parameter was kept quite stable in U-5 fillets $(p=0.159)$. Considered as a whole, differences in redness $\left(a^{*}\right)$ between both experimental groups were not significant during the storage period. And finally, $b^{*}$ parameter increased owing to storage time in both experimental groups, but differences between the dietary treatments were kept during the 10-d period, being values for this parameter consistently higher in U-5 fillets.

Colour parameters were also measured on the flesh side of fillets. Overall, $U$. ohnoi supplementation only yielded differences in $L^{*}$ and $b^{*}$ parameters $(p=0.032$, and $p<0.001$, respectively). Cold storage decreased both $L^{*}$ and $a^{*}$, whereas $b^{*}$ was increased.

\section{5. $p H$ and water holding capacity (WHC)}

Ulva supplementation led to lower values for $\mathrm{pH}$ in Senegalese sole fillets of 270-d throughout the cold storage period (Fig. 3), although differences became significant only after 10-d cold storage period. Initial $\mathrm{pH}$ values were similar in both lots (around 6.21), whereas after 10-d values were 6.35 and 6.41 for U-5 and control groups, respectively.

As expected, WHC decreased significantly $(p=0.003)$ throughout the storage time in C fillets (Fig. 4), ranging from $65.3 \%(t=0)$ to $58.4 \%$ after 10 days. However, values for U-5 fillets not only were consistently higher for this parameter during the complete period, but also remained basically unchanged from the beginning $(65.8 \%)$ to the end $(64.0 \%)$ of the storage period. In fact, considered as a whole, muscle of Ulva-supplemented fish yielded significantly higher $(p=0.006)$ figures for WHC than control animals.

\subsection{Texture profile analysis (TPA)}

The effects of the experimental diets on fillet textural parameters measured in the pigmented side are summarized in Table 5. With regard to hardness, the addition of Ulva yielded consistently higher values for this parameter compared to control fillets throughout the complete post-thawing period. During cold storage, hardness decreased markedly in C fillets, whereas muscle softness was delayed in U-5 fillets, in such a 
Table 3

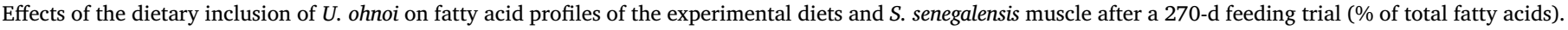

\begin{tabular}{|c|c|c|c|c|c|c|}
\hline \multirow[t]{2}{*}{ Fatty acids } & \multirow[t]{2}{*}{ Ulva meal } & \multicolumn{2}{|l|}{ Diets } & \multicolumn{2}{|l|}{ Fish muscle } & \multirow[t]{2}{*}{$p$} \\
\hline & & $\mathrm{C}$ & U-5 & $\mathrm{C}$ & U-5 & \\
\hline $14: 0$ & $0.59 \pm 0.04$ & $3.34 \pm 0.04$ & $3.43 \pm 0.01$ & $3.34 \pm 0.16^{\mathrm{b}}$ & $2.59 \pm 0.05^{\mathrm{a}}$ & 0.001 \\
\hline $16: 0$ & $37.69 \pm 0.30$ & $17.23 \pm 0.02$ & $17.78 \pm 0.03$ & $19.37 \pm 0.68$ & $19.76 \pm 0.53$ & n.s. \\
\hline $18: 0$ & $0.67 \pm 0.08$ & $3.61 \pm 0.03$ & $3.56 \pm 0.02$ & $5.10 \pm 0.22^{\mathrm{a}}$ & $6.10 \pm 0.22^{\mathrm{b}}$ & 0.005 \\
\hline $20: 0$ & $1.87 \pm 0.04$ & - & - & - & - & \\
\hline $16: 1 \mathrm{n} 7$ & $4.09 \pm 0.48$ & $4.73 \pm 0.07$ & $4.85 \pm 0.04$ & $4.65 \pm 0.19^{b}$ & $3.59 \pm 0.09^{\mathrm{a}}$ & $<0.001$ \\
\hline $18: 1 \mathrm{n} 7$ & $0.82 \pm 0.06$ & $2.79 \pm 0.02$ & $2.92 \pm 0.01$ & $2.69 \pm 0.08^{\mathrm{b}}$ & $2.40 \pm 0.03^{\mathrm{a}}$ & 0.004 \\
\hline $18: \ln 9$ & $11.48 \pm 0.67$ & $14.68 \pm 0.03$ & $14.71 \pm 0.01$ & $15.92 \pm 0.40^{\mathrm{b}}$ & $14.60 \pm 0.11^{\mathrm{a}}$ & 0.005 \\
\hline $20: 1 \ln 9$ & $0.82 \pm 0.08$ & $5.78 \pm 0.15$ & $5.67 \pm 0.01$ & $1.85 \pm 0.31^{\mathrm{b}}$ & $1.25 \pm 0.02^{\mathrm{a}}$ & 0.020 \\
\hline $18: 2 \mathrm{n} 6$ & $2.55 \pm 0.20$ & $8.06 \pm 0.05$ & $8.05 \pm 0.00$ & $5.24 \pm 0.16^{b}$ & $4.95 \pm 0.07^{\mathrm{a}}$ & 0.044 \\
\hline $18: 3 n 3$ & $9.70 \pm 0.05$ & $1.41 \pm 0.02$ & $1.51 \pm 0.14$ & $0.87 \pm 0.05^{\mathrm{b}}$ & $0.73 \pm 0.02^{\mathrm{a}}$ & 0.011 \\
\hline $16: 4 \mathrm{n} 3$ & $9.41 \pm 0.05$ & $0.49 \pm 0.01$ & $0.49 \pm 0.01$ & $0.62 \pm 0.01^{b}$ & $0.52 \pm 0.02^{\mathrm{a}}$ & $<0.001$ \\
\hline $18: 4 n 3$ & $14.64 \pm 0.04$ & $1.47 \pm 0.05$ & $1.42 \pm 0.01$ & $1.16 \pm 0.05^{\mathrm{b}}$ & $1.00 \pm 0.06^{\mathrm{a}}$ & 0.019 \\
\hline $20: 4 n 6$ & - & $1.01 \pm 0.02$ & $0.99 \pm 0.01$ & $1.39 \pm 0.05^{\mathrm{a}}$ & $1.91 \pm 0.11^{\mathrm{b}}$ & 0.001 \\
\hline $20: 4 n 3$ & - & $0.56 \pm 0.12$ & $0.60 \pm 0.00$ & $0.71 \pm 0.03$ & $0.64 \pm 0.07$ & n.s. \\
\hline $20: 5 n 3$, EPA & $0.31 \pm 0.03$ & $7.95 \pm 0.02$ & $7.84 \pm 0.03$ & $5.73 \pm 0.14^{\mathrm{a}}$ & $6.20 \pm 0.21^{\mathrm{b}}$ & 0.032 \\
\hline $22: 5 n 3$ & $0.43 \pm 0.05$ & $7.00 \pm 0.08$ & $6.99 \pm 0.04$ & $7.10 \pm 0.20^{\mathrm{b}}$ & $6.60 \pm 0.03^{\mathrm{a}}$ & 0.011 \\
\hline $22: 6 n 3$, DHA & - & $14.37 \pm 0.19$ & $13.99 \pm 0.18$ & $18.98 \pm 0.54^{\mathrm{a}}$ & $23.39 \pm 0.88^{b}$ & 0.001 \\
\hline $\begin{array}{l}\text { Total lipids } \\
\qquad\left(\mathrm{mg} \mathrm{g}^{-1} \text { d.w.) }\right.\end{array}$ & $27.03 \pm 0.90$ & $124.02 \pm 3.10$ & $120.23 \pm 5.21$ & $74.82 \pm 3.71^{\mathrm{a}}$ & $60.21 \pm 0.84^{\mathrm{b}}$ & 0.015 \\
\hline $\begin{array}{l}\text { Total FA } \\
\qquad\left(\mathrm{mg} \mathrm{g}^{-1} \text { d.w.) }\right.\end{array}$ & $21.89 \pm 1.12$ & $93.18 \pm 1.14$ & $90.20 \pm 3.64$ & $71.06 \pm 2.49$ & $57.19 \pm 1.52$ & 0.005 \\
\hline$\Sigma$ SFA & $40.82 \pm 0.46$ & $24.18 \pm 0.03$ & $24.76 \pm 0.05$ & $27.80 \pm 1.06$ & $28.44 \pm 0.71$ & n.s. \\
\hline ¿MUFA & $16.69 \pm 1.29$ & $27.98 \pm 0.12$ & $28.15 \pm 0.04$ & $25.11 \pm 0.97^{b}$ & $21.84 \pm 0.11^{\mathrm{a}}$ & 0.004 \\
\hline ¿PUFA & $37.04 \pm 0.42$ & $41.82 \pm 0.12$ & $41.40 \pm 0.14$ & $41.18 \pm 1.17^{\mathrm{a}}$ & $45.19 \pm 0.94^{\mathrm{b}}$ & 0.003 \\
\hline Other FA & $5.45 \pm 0.10$ & $4.77 \pm 0.05$ & $4.36 \pm 0.06$ & $5.25 \pm 0.23^{\mathrm{b}}$ & $4.44 \pm 0.14^{\mathrm{a}}$ & 0.020 \\
\hline$\Sigma \mathrm{n}-3$ & $34.49 \pm 0.22$ & $32.75 \pm 0.06$ & $32.36 \pm 0.12$ & $34.55 \pm 0.98^{\mathrm{a}}$ & $38.33 \pm 0.77^{\mathrm{b}}$ & 0.006 \\
\hline$\Sigma \mathrm{n}-6$ & $2.55 \pm 0.22$ & $9.06 \pm 0.06$ & $9.04 \pm 0.01$ & $6.63 \pm 0.20$ & $6.86 \pm 0.17$ & n.s. \\
\hline$\Sigma \mathrm{n}-9$ & $11.78 \pm 0.75$ & $20.47 \pm 0.17$ & $20.38 \pm 0.02$ & $17.77 \pm 0.70^{\mathrm{a}}$ & $15.86 \pm 0.10^{\mathrm{b}}$ & 0.009 \\
\hline $\mathrm{n} 3 / \mathrm{n} 6$ & $13.53 \pm 1.10$ & $3.61 \pm 0.02$ & $3.58 \pm 0.01$ & $5.21 \pm 0.02^{\mathrm{a}}$ & $5.59 \pm 0.03^{\mathrm{b}}$ & $<0.001$ \\
\hline EPA/DHA & - & $0.55 \pm 0.01$ & $0.56 \pm 0.01$ & $0.30 \pm 0.01^{\mathrm{b}}$ & $0.27 \pm 0.01^{\mathrm{a}}$ & $<0.001$ \\
\hline IA $^{1}$ & - & - & - & $0.49 \pm 0.02^{b}$ & $0.45 \pm 0.00^{\mathrm{a}}$ & $<0.001$ \\
\hline $\mathrm{IT}^{2}$ & - & - & - & $0.21 \pm 0.01$ & $0.20 \pm 0.00$ & n.s. \\
\hline $\mathrm{FLQ}^{3}$ & - & - & - & $24.14 \pm 1.15$ & $29.59 \pm 1.08$ & 0.028 \\
\hline
\end{tabular}

Dietary treatments are C: control diet; U-5: 5\% U. ohnoi meal inclusion Values with different lowercase superscript indicate significant differences in muscle lipids attributed to dietary treatments $(p<0.05)$. d.w.: dry weight. FA: fatty acids; SFA: saturated fatty acids; MUFA: monounsaturated fatty acids; PUFA: polyunsaturated fatty acids; EPA: eicosapentaenoic acid; DHA: docosahexaenoic acid. ${ }^{1}$ IA: index of atherogenicity $=(12: 0+4 * 14: 0+16: 0) /[(\mathrm{n}-6+\mathrm{n}-3)$ PUFAs $+18: 1+$ other MUFAs $] ;{ }^{2}$ IT: index of thrombogenicity $=(14: 0+16: 0+18: 0) /[(0.5 * 18: 1)+(0.5 * \Sigma$ MUFAs $)+(0.5 * \mathrm{n}-6$ PUFAs $)+(3 * \mathrm{n}-3$ PUFAs $)+(\mathrm{n}-3 / \mathrm{n}-$ 6) $] ;{ }^{3}$ FLQ (\%): fish lipid quality $=[(20: 5 n-3+22: 6 n-3) /$ total lipid $] \times 100$. Values are expressed as average \pm sd $(n=9$ fish per dietary treatment). n.s.: not significant.

manner that significant differences between both experimental groups were kept up to 8 days post-thawing. At the end of the storage period, firmness evened in both experimental groups.

Fillet springiness and cohesiveness followed the same trend in both lots throughout cold storage, and hence, values decreased as storage time increased. However, no significant differences could be attributable to dietary treatments. Roughly, gumminess and chewiness also followed a tendency parallel to that observed for hardness, with values tending to be higher in Ulva-fed fillets.

Considering the complete storage time, none of the other TPA parameters studied (springiness, resilience, and cohesiveness) were, overall, influenced significantly by storage time or dietary treatment.

\section{Discussion}

The interest in seaweeds as nutrient source has increased notably in the last years, taking into account its sustainability and, hence, the acceptability of its use in aquafeeds [1]. Literature exploring the use of macroalgae as a major ingredient is available, reporting satisfactory effects on fish growth, immune response and protein and lipid uptake $[3,33,34]$. However, owing to a wide range of practical limitations, nowadays the growing interest in such substances is mainly related to the possibility of shaping different quality properties of fish for human consumption [35], and thus some studies have focused on the effects of macroalgae-supplemented finishing feeds on fillet quality parameters in different fish species [4-7].
In this regard, whereas the inclusion of certain amounts of macroalgae in aquafeeds targeting fish early developmental stages might well be economically feasible, as well as fully justified by their positive impact on different physiological aspects during the pre-ongrowing and ongrowing periods of the productive cycle, however, this strategy might lead to increased feeding costs and, subsequently, to lower profitability when it comes to finishing diets.

In this work we explored the possibility of modifying some quality attributes of Senegalese sole as a result of feeding animals with macroalgae-enriched diets at low inclusion level for a limited period of time (90 d). To our knowledge, no studies have been carried out aimed at evaluating the potential effects of an interrupted feeding strategy on the quality attributes of fish at latter stages of the productive cycle.

Given that, as mentioned, the aptitude of Senegalese sole for freezing is remarkable, fillets were also frozen and stored for 6 months at $-20{ }^{\circ} \mathrm{C}$, in order to assess the potential effects of the experimental feeds on the quality of the fillets subjected to this treatment, especially with regard to lipid oxidation.

Related to muscle composition, the most notable result was the significantly lower lipid content of fish fed with $U$. ohnoi diet after 270$\mathrm{d}$ (Table 3). These animals yielded a final weight similar to that of the control batch. This result is in agreement with previous studies $[4,36]$, pointing to decreased lipid content in fish fed with diets supplemented with Ulva meal. Previous studies have attributed the effects on lipid metabolism and muscle fat deposition to the high content in vitamin $\mathrm{C}$ of Ulva [37,38], although it is doubtful that this specific substance 
Table 4

Changes in skin (ocular side) colour parameters and muscle thiobarbituric acidreactive substances (TBARS) content in $S$. senegalensis fresh fillets at different sampling times (45, 90 and $270 \mathrm{~d}$ ) of the feeding trial.

\begin{tabular}{lllll}
\hline Colour parameters & $\begin{array}{l}\text { Time } \\
(\mathrm{d})\end{array}$ & $\mathrm{C}$ & $\mathrm{U}-5$ & $p$ \\
& & & \\
\hline$L^{*}$ & 45 & $48.38 \pm 1.12^{\mathrm{a}}$ & $57.25 \pm 1.34^{\mathrm{b}}$ & $<0.001$ \\
& 90 & $47.60 \pm 1.26^{\mathrm{a}}$ & $54.78 \pm 3.39^{\mathrm{b}}$ & $<0.001$ \\
& 270 & $48.02 \pm 0.97^{\mathrm{a}}$ & $56.41 \pm 2.62^{\mathrm{b}}$ & $<0.001$ \\
& $p$ & n.s. & n.s. & \\
$a^{*}$ & 45 & $0.91 \pm 0.08^{\mathrm{a}}$ & $0.48 \pm 0.05^{\mathrm{a}}$ & $<0.001$ \\
& 90 & $0.84 \pm 0.33^{\mathrm{a}}$ & $0.46 \pm 0.03^{\mathrm{a}}$ & $<0.001$ \\
& 270 & $0.89 \pm 0.21$ & $0.48 \pm 0.12$ & $<0.001$ \\
$b^{*}$ & $p$ & n.s. & n.s. & \\
& 45 & $3.86 \pm 1.01$ & $6.29 \pm 0.84^{\mathrm{a}}$ & 0.001 \\
& 90 & $3.76 \pm 0.17$ & $6.31 \pm 0.34^{\mathrm{a}}$ & $<0.001$ \\
& 270 & $3.92 \pm 0.54$ & $6.37 \pm 0.37$ & $<0.001$ \\
& $p$ & n.s. & n.s. & \\
TBARS & 45 & $0.96 \pm 0.19$ & $0.75 \pm 0.16$ & n.s. \\
$(m g$ MDA kg & & & \\
& 90 & $0.89 \pm 0.21$ & $0.77 \pm 0.22$ & n.s. \\
& 270 & $1.06 \pm 0.44$ & $0.92 \pm 0.23$ & n.s. \\
& $p$ & n.s. & n.s. & \\
& & & &
\end{tabular}

Dietary treatments are C: control diet; U-5: 5\% U. ohnoi meal inclusion. Values with different lowercase superscript indicate significant differences attributed to feed supplementation with 5\% U. ohnoi $(p<0.05)$. Colour parameters $L^{*}, a^{*}$ and $b *$ stand for lightness, redness, and yellowness, respectively, according to Commission Internationale de l'Eclairage (CIE, 1986). TBARS: thiobarbituric acid-reactive substances. MDA: malonyl dialdehyde. Values are expressed as average $\pm \operatorname{sd}(n=15$ and $n=9$ for colour and TBARS, respectively). n.s.: not significant.

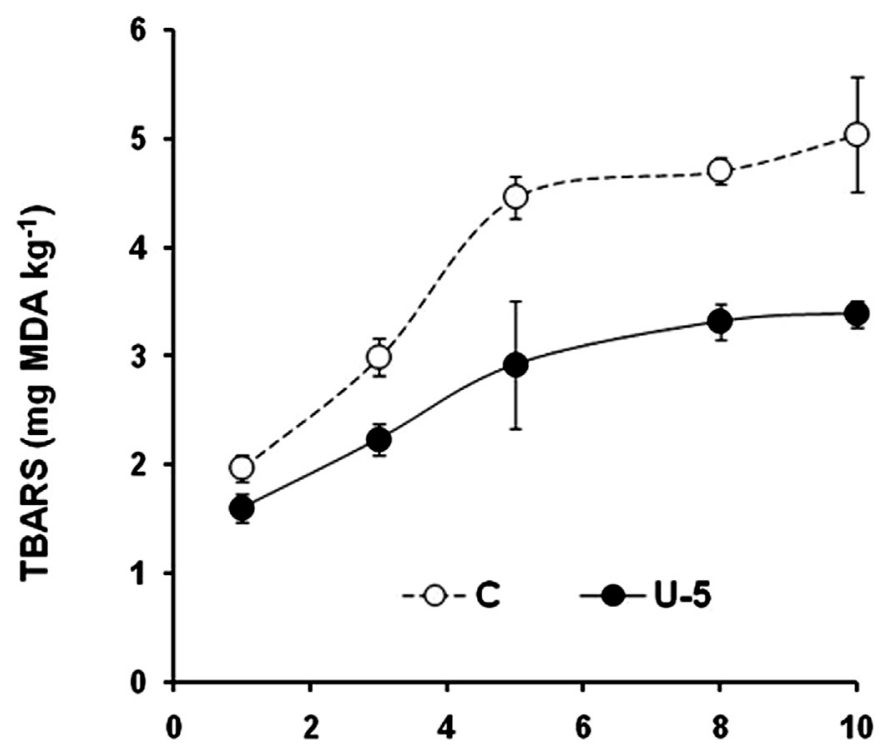

\section{Days post-thawing}

Fig. 1. Lipid oxidation (estimated by thiobarbituric acid-reactive substances, TBARS) of $S$. senegalensis muscle during a 10 -d post-thawing cold storage $\left(4^{\circ} \mathrm{C}\right)$ period. Dietary treatments are C: control diet; U-5: 5\% inclusion U. ohnoi diet. Values are expressed as average $\pm \operatorname{sd}(n=5)$.

might have played a significant role in our study, taking into account the low inclusion level of the macroalgae.

The fact that such differences were significant acquires special relevance taking into account that Solea sp. are lean fish, with muscle lipid contents around 6-8\% [39,40].

Not only quantitative but, interestingly, also qualitative differences were found in muscle lipids after 270-d (Table 3), which could be attributed to early dietary effects on juvenile fish. Although dietary FA

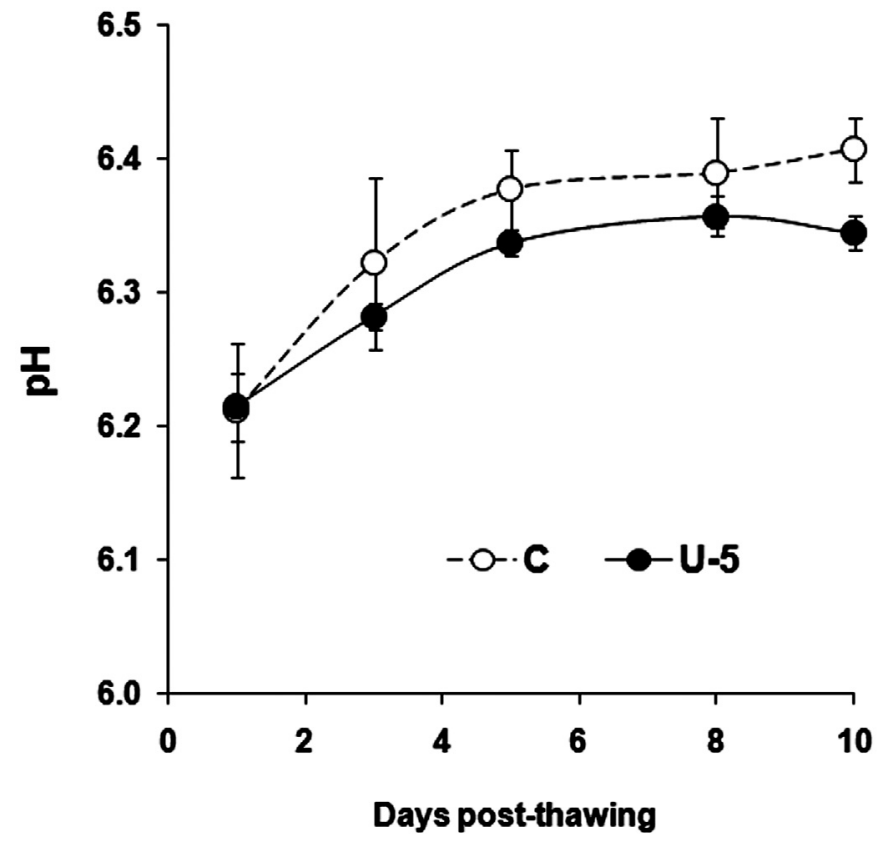

Fig. 2. Changes in $S$. senegalensis fillet $\mathrm{pH}$ during the 10 -d cold storage $\left(4^{\circ} \mathrm{C}\right)$ period. Dietary treatments are C: control diet; U-5: 5\% inclusion $U$. ohnoi diet. Values are expressed as average \pm sd $(n=5)$.

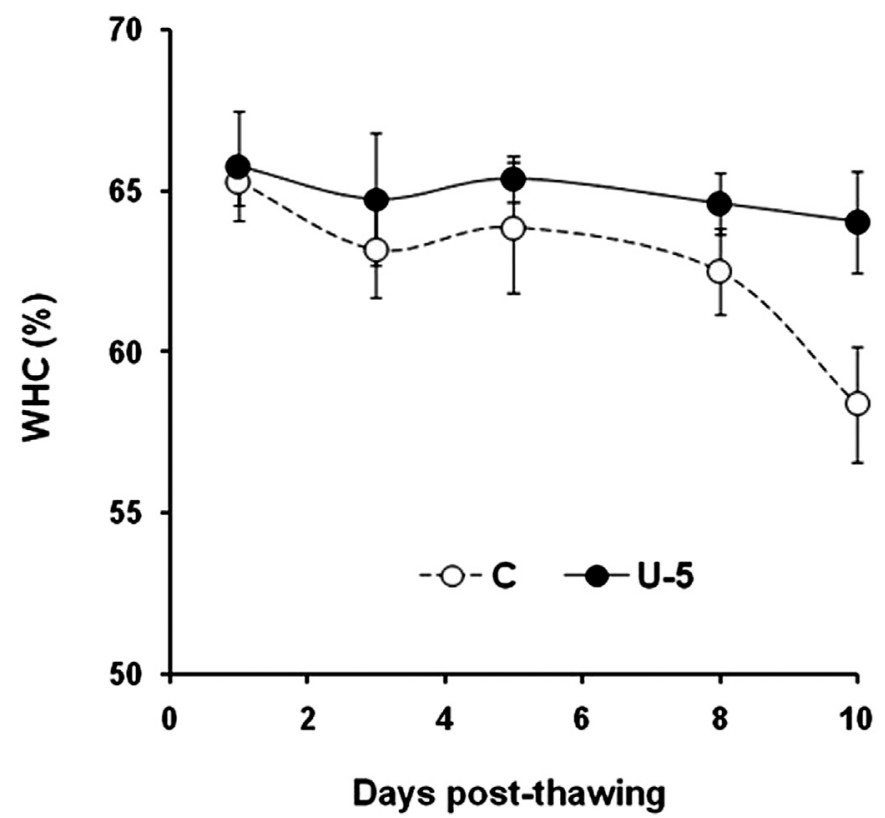

Fig. 3. Changes in $S$. senegalensis fillet water holding capacity (WHC) throughout the 10 -d cold storage $\left(4^{\circ} \mathrm{C}\right)$ period. Dietary treatments are C: control diet; U-5: 5\% inclusion $U$. ohnoi diet. Values are expressed as average \pm sd $(n=5)$.

profiles are generally reflected in fish muscle [41-44], the significant increase in fillet n-3-PUFAs observed in our work for U-5-fed fish can't be attributed to differences in dietary FA as a result of Ulva inclusion. As already mentioned, Ulva inclusion essentially didn't change fatty acid profile of U-5 diet compared to control diet (Table 3).

Thereby, U-5 diet seemed to be responsible for a certain degree of $n$ 3-PUFA selective retention in muscle, whilst the opposite effect was observed with regard to MUFAs (25.1 vs. $21.8 \%$ ). This phenomenon has already been described for larvae of this species [42]. The overall relative increase of structural fatty acids in muscle (EPUFA, 41.2 vs. 
SKIN
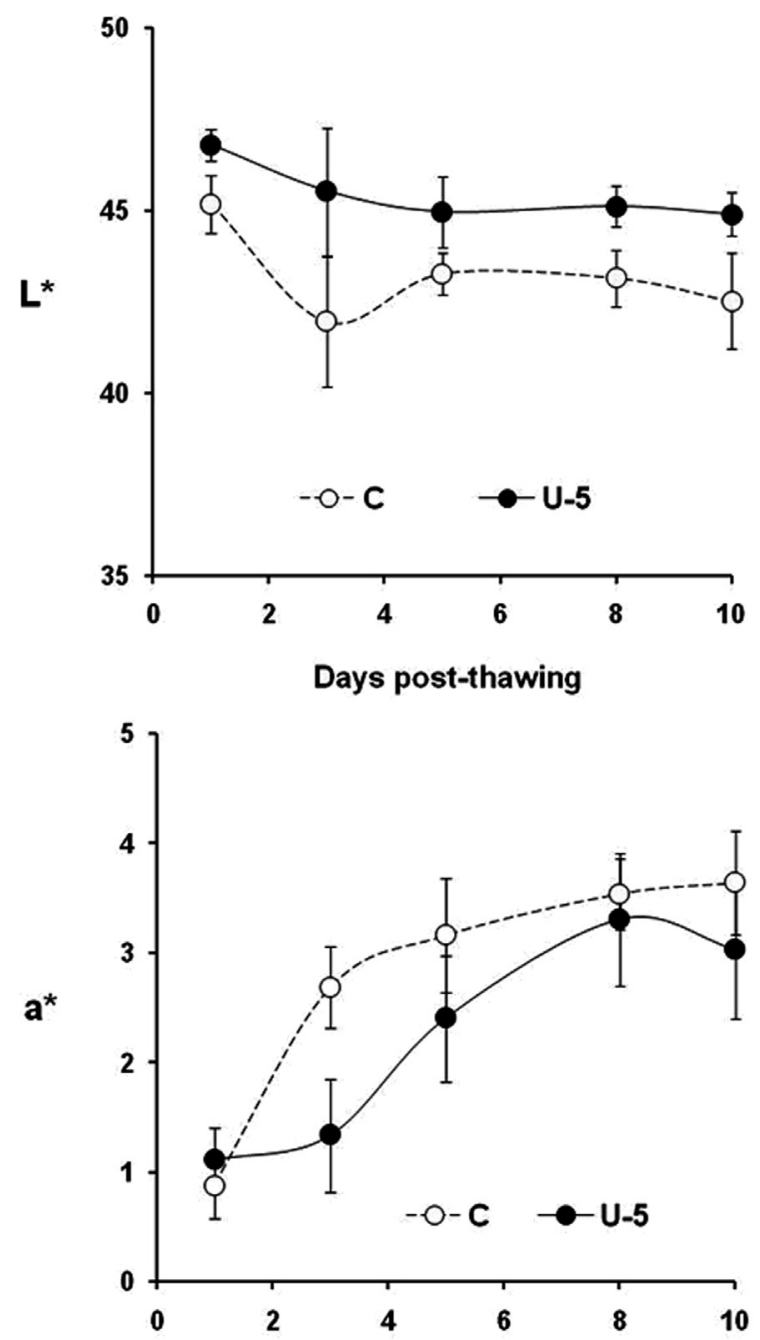

Days post-thawing

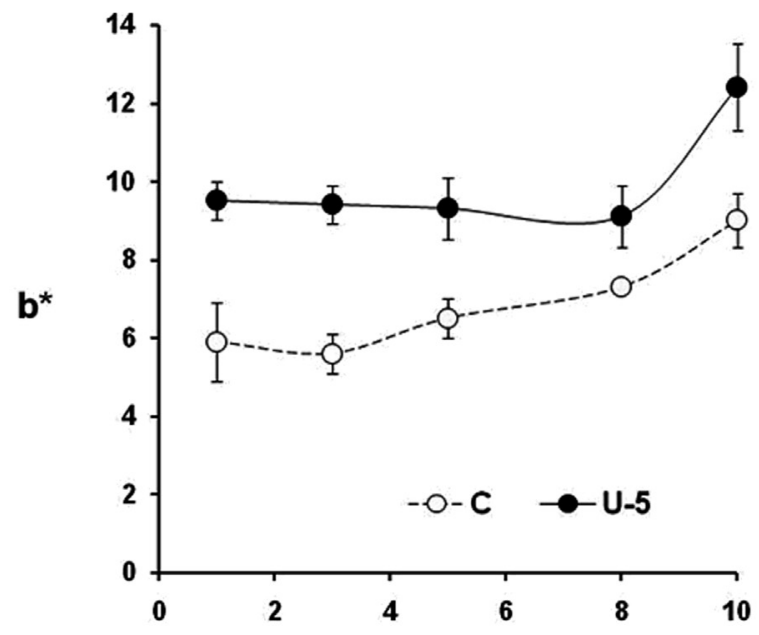

Days post-thawing
FLESH
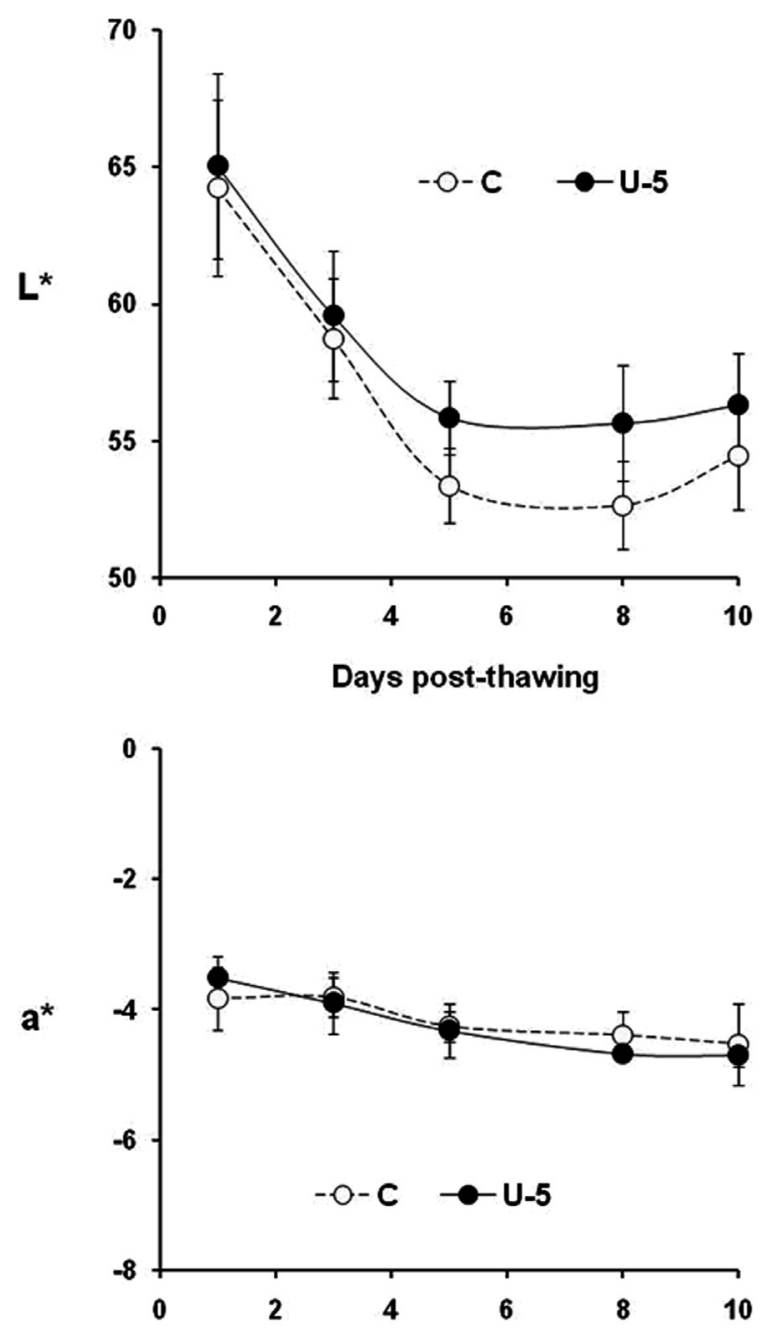

Days post-thawing

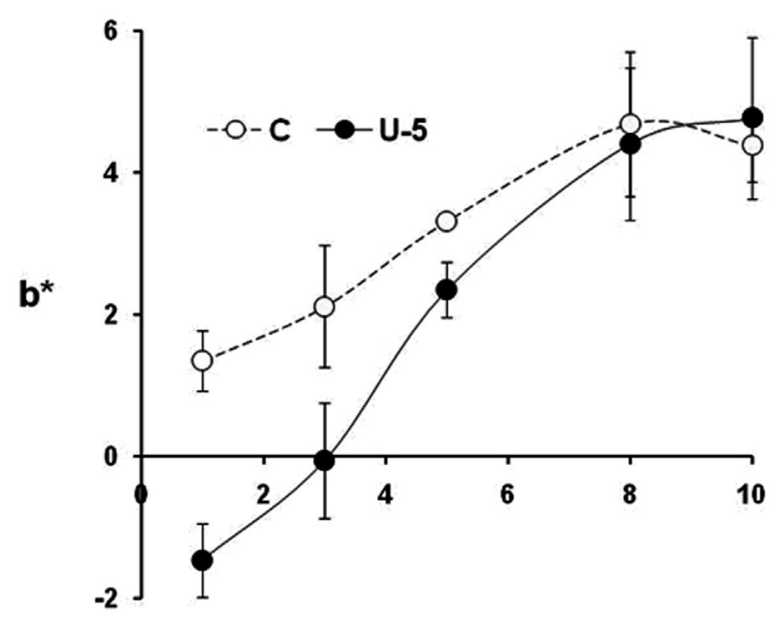

Days post-thawing

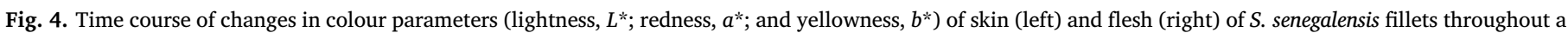

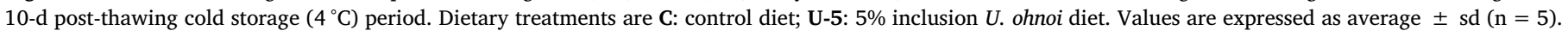


Table 5

Changes in texture profile analysis (TPA) parameters during post-thawing cold storage $\left(4^{\circ} \mathrm{C}\right)$ of fillets as influenced by the experimental diets after a $270-\mathrm{d}$ feeding trial.

\begin{tabular}{|c|c|c|c|c|}
\hline Texture parameters & $\begin{array}{l}\text { Time } \\
\text { (d) }\end{array}$ & $\mathrm{C}$ & U-5 & $p$ \\
\hline \multirow{6}{*}{$\begin{array}{l}\text { Hardness } \\
\text { (N) }\end{array}$} & 1 & $34.82 \pm 0.84^{\mathrm{a}, \mathrm{B}}$ & $39.58 \pm 1.87^{\mathrm{b}, \mathrm{D}}$ & 0.004 \\
\hline & 3 & $31.11 \pm 2.43^{\mathrm{a}, \mathrm{B}}$ & $36.26 \pm 2.86^{\mathrm{b}, \mathrm{CD}}$ & 0.033 \\
\hline & 5 & $29.97 \pm 1.37^{\mathrm{B}}$ & $33.12 \pm 2.47^{\mathrm{BC}}$ & n.s. \\
\hline & 8 & $21.79 \pm 2.85^{\mathrm{a}, \mathrm{A}}$ & $31.22 \pm 4.77^{\mathrm{b}, \mathrm{B}}$ & 0.015 \\
\hline & 10 & $19.35 \pm 2.70^{\mathrm{A}}$ & $21.95 \pm 2.68^{\mathrm{A}}$ & n.s. \\
\hline & $p$ & $<0.001$ & $<0.001$ & \\
\hline \multirow{6}{*}{$\begin{array}{l}\text { Springiness } \\
\text { (mm) }\end{array}$} & 1 & $0.67 \pm 0.11^{\mathrm{a}}$ & $0.81 \pm 0.03^{\mathrm{b}}$ & 0.048 \\
\hline & 3 & $0.92 \pm 0.06$ & $0.95 \pm 0.04$ & n.s. \\
\hline & 5 & $0.86 \pm 0.09$ & $0.87 \pm 0.12$ & n.s. \\
\hline & 8 & $0.71 \pm 0.06$ & $0.77 \pm 0.06$ & n.s. \\
\hline & 10 & $0.79 \pm 0.08$ & $0.79 \pm 0.08$ & n.s. \\
\hline & $p$ & n.s. & n.s. & \\
\hline \multirow[t]{6}{*}{ Cohesiveness } & 1 & $0.44 \pm 0.04$ & $0.45 \pm 0.07$ & n.s. \\
\hline & 3 & $0.37 \pm 0.07$ & $0.40 \pm 0.04$ & n.s. \\
\hline & 5 & $0.43 \pm 0.05$ & $0.40 \pm 0.02$ & n.s. \\
\hline & 8 & $0.36 \pm 0.07$ & $0.39 \pm 0.01$ & n.s. \\
\hline & 10 & $0.41 \pm 0.05$ & $0.40 \pm 0.04$ & n.s. \\
\hline & $p$ & n.s. & n.s. & \\
\hline \multirow{6}{*}{$\begin{array}{l}\text { Gumminess } \\
\qquad\left(\mathrm{N} \mathrm{mm}^{-2}\right)\end{array}$} & 1 & $15.75 \pm 2.04^{\mathrm{C}}$ & $18.01 \pm 3.52^{\mathrm{B}}$ & n.s. \\
\hline & 3 & $11.58 \pm 2.17^{\mathrm{B}}$ & $12.44 \pm 2.96^{\mathrm{A}}$ & n.s. \\
\hline & 5 & $13.90 \pm 2.13^{\mathrm{BC}}$ & $12.91 \pm 3.26^{\mathrm{A}}$ & n.s. \\
\hline & 8 & $7.90 \pm 1.99^{\mathrm{A}}$ & $10.33 \pm 2.57^{\mathrm{A}}$ & n.s. \\
\hline & 10 & $7.97 \pm 1.89^{\mathrm{A}}$ & $8.97 \pm 1.70^{\mathrm{A}}$ & n.s. \\
\hline & $p$ & $<0.001$ & 0.005 & \\
\hline \multirow{6}{*}{$\begin{array}{l}\text { Chewiness } \\
\text { (N mm) }\end{array}$} & 1 & $10.41 \pm 1.41^{\mathrm{a}, \mathrm{B}}$ & $14.61 \pm 3.03^{\mathrm{b}, \mathrm{D}}$ & 0.046 \\
\hline & 3 & $10.72 \pm 2.39^{\mathrm{B}}$ & $13.55 \pm 1.15^{\mathrm{CD}}$ & n.s. \\
\hline & 5 & $11.16 \pm 1.45^{\mathrm{B}}$ & $11.51 \pm 1.97^{\mathrm{BC}}$ & n.s. \\
\hline & 8 & $5.59 \pm 1.29^{\mathrm{a}, \mathrm{A}}$ & $9.41 \pm 1.30^{\mathrm{B}}$ & 0.006 \\
\hline & 10 & $6.22 \pm 0.95^{\mathrm{A}}$ & $6.85 \pm 0.49^{\mathrm{A}}$ & n.s. \\
\hline & $p$ & $<0.001$ & $<0.001$ & \\
\hline \multirow{6}{*}{$\begin{array}{l}\text { Resilience } \\
\qquad\left(\mathrm{N} \mathrm{mm}^{-1}\right)\end{array}$} & 1 & $0.12 \pm 0.00^{\mathrm{BC}}$ & $0.10 \pm 0.01^{\mathrm{A}}$ & n.s. \\
\hline & 3 & $0.11 \pm 0.01^{\mathrm{AB}}$ & $0.10 \pm 0.02^{\mathrm{A}}$ & n.s. \\
\hline & 5 & $0.13 \pm 0.01^{\mathrm{C}}$ & $0.11 \pm 0.02^{\mathrm{A}}$ & n.s. \\
\hline & 8 & $0.10 \pm 0.01^{\mathrm{A}}$ & $0.10 \pm 0.01^{\mathrm{A}}$ & n.s. \\
\hline & 10 & $0.12 \pm 0.01^{\mathrm{BC}}$ & $0.13 \pm 0.01^{\mathrm{B}}$ & n.s. \\
\hline & $p$ & 0.018 & 0.038 & \\
\hline
\end{tabular}

Dietary treatments are C: control diet; U-5: 5\% U. ohnoi meal inclusion. Values with different lowercase indicate significant differences attributed to $5 \% U$. ohnoi $(p<0.05)$. Values with different uppercase indicate significant differences attributed to post-thawing storage time at $4{ }^{\circ} \mathrm{C}(p<0.05)$. Values are expressed as average \pm sd $(n=5)$. n.s.: not significant.

45.2\%) was based mostly on DHA, followed by EPA, a fact that is particularly interesting from the point of view of the human nutrition, even if total lipids were significantly lower in fish fed on U-5 diet. Indeed, this phenomenon is also reflected in the significant increase of fish lipid quality index (FLQ), and $\mathrm{n} 3 / \mathrm{n} 6$ ratio in U-5 fish, as well as in the reduction of the index of atherogenicity (IA), altogether suggesting valuable effects. These results are in agreement with previous studies pointing to significantly high levels of n-3 fatty acids, not least of EPA and DHA, in the liver of rainbow trout (Oncorhynchus mykiss) fed with 5 and $10 \%$ Ulva meal [45].

Previous studies have also reported noticeable effects of algal meals on fish lipid metabolism $[7,39]$, which has been attributed to some kind of functional activities in this regard [46,47] that remain to be fully ascertained.

Consequently, the results point not only to a quantitative effect, but also to some kind of qualitative influence on the metabolism of lipids. It is especially remarkable the fact that animals were fed on the diet containing Ulva meal only for $90 \mathrm{~d}$ out of $270 \mathrm{~d}$ of the feeding trial. To our knowledge, this sort of deferred effect has not been reported previously.

The literature has reported not only the influence of macroalgae meal on lipid metabolism, but also certain effects on muscle protein. Thus, several studies observed that fish fed with Ulva-enriched diets showed increased muscle protein content (Azaza et al. [48]; Ergün et al. [49] in tilapia, Oreochromis niloticus; Güroy et al. [13]; Yildirim et al. [36] in rainbow trout). In our study, this phenomenon was observed only to a certain extent, given that samples of fish fed with U-5 diet tended to show higher protein content than control fish (Table 2) at least up to day 90 . However, differences were significant only at early stages of the feeding trial, namely after $45 \mathrm{~d}$, but from this time onwards values tended to be similar, and they were virtually equal after $270 \mathrm{~d}$. Some authors have proposed that the high protein content of macroalgae meals might account for increased protein retention [50]. However, in our specific research, it is unlikely that such kind of quantitative effect might have occurred, owing to the isoproteic nature of the feeds used in the feeding trial (Table 1).

Macroalgae are reputed natural sources of functional compounds with potential interest in aquaculture [7,51], among which those with antioxidant properties outstands. With regard to Ulva sp., this genus is rich in phenolics, vitamins regarded as antioxidants (A, C and E [52]), natural pigments such as chlorophylls, xanthophylls, and carotenoids [53]. Additionally, Ulva is rich in ulvan, a sulphated polysaccharide with recognised antioxidant properties $[54,55]$.

It might well be the abundance of antioxidant substances what could explain the prevention of lipid oxidation observed in our study, although not in fresh fish (Table 4), but in frozen fillets (Fig. 1). Hence, the inclusion of 5\% Ulva didn't yield significantly lower TBARS values in fresh fish compared to control batch, irrespectively of the sampling time (45, 90, and $270 \mathrm{~d})$. Scarce literature is available aimed at assessing the effects of macroalgae supplementation on the oxidation of fish lipids, albeit Moroney et al. [6] reported no effect of Ulva rigida on the oxidative status of salmon lipids after a 19-w feeding trial, in agreement with our results after $270 \mathrm{~d}$ (Table 4). It is remarkable that values remained low in all samples, consistently below $2 \mathrm{mg} \mathrm{MDA} \mathrm{kg}^{-1}$, what is considered as fish of excellent quality [56].

In our study, fillets obtained at day 270 were then frozen for a 6month period, in order to assess the possible influence of Ulva ohnoi on quality parameters, and not least, on lipid oxidation. In this regard, the results indicate again that the macroalgae didn't yield any difference in TBARS immediately after thawing the fillets. However, clear disparities were observed in TBARS throughout the post-thawing cold storage period ( 10 days, $\left.4^{\circ} \mathrm{C}\right)$, in which differences were significant at any sampling time between both groups (Fig. 1).

Even if MDA increased throughout the post-thawing cold storage period, it is notable that values in control fillets didn't increase over $6 \mathrm{mg}$ de MDA kg ${ }^{-1}$ after 10 days at $4{ }^{\circ} \mathrm{C}$. Nevertheless, what is more remarkable is the fact that U-5 fillets under the specified conditions showed TBARS values below $3 \mathrm{mgdeMDA} \mathrm{kg}^{-1}$ at day 10 postthawing.

The study of Moroney et al. [6] is the only one accessed that involved post-mortem assessment of Ulva on fish quality parameters. With regard to lipid oxidation, these authors didn't observed any impact of the macroalgae supplementation throughout a 15-d post-mortem cold storage period. These results disagree with our study, although some methodological differences might well have account for such disparities. For instance, i) the composition of salmon and sole muscle is very different, not least with regard to lipid contents; ii) fresh fillets were used in the study cited, whereas defrosted fish in ours; and in addition, iii) samples were permanently kept under a $\mathrm{N}_{2} / \mathrm{CO}_{2}$ modified atmosphere in their research (which would explain their low TBARS values at any sampling time up to $15 \mathrm{~d}$ ), whereas our fillets were kept under natural atmosphere.

The colour of commercial fish is a relevant aspect of overall quality that accounts decisively for its market acceptability [16,57]. As mentioned, macroalgae are acknowledged as natural sources of a wide variety of pigments [58], and Ulva isn't an exception to this general rule [12]. Compared to wild fish, one of the main disadvantages of aquacultured fish, in terms of consumer's acceptability, consists of poor skin and muscle pigmentation. In this regard, for some farmed species, such 
as salmonids, the dietary inclusion of pigments is compulsory in order to meet the market requirements. For other species, such as Senegalese sole, the skin pigmentation (especially that of the ocular, pigmented side) is also a key factor that determines the purchase decision and, consequently, its commercial value [22].

In this context, the possible impact of Ulva supplementation on the instrumental colour parameters of the ocular side skin was also assessed in this study, under a double perspective: i) the effects during the 270-d feeding trial at three sampling times (Table 4); and ii) the possible influence on defrosted fillets stored at $4{ }^{\circ} \mathrm{C}$ for a 10 -d period (Fig. 2).

With regard to fresh fish, the three parameters measured $\left(L^{*}, a^{*}\right.$, and $b^{*}$ ) were affected significantly as a result of Ulva supplementation, irrespectively of the sampling time (Table 4$)$. Thus, lightness $\left(L^{*}\right)$ and yellowness $\left(b^{*}\right)$ increased, but redness $\left(a^{*}\right)$ decreased, these modifications together suggesting increased consumer's acceptability for this specific flatfish [22]. Changes in colour parameters might well be linked to the presence of macroalgal pigments, as reported previously $[5,6,35]$. It should be highlighted that 270-d fish kept the differences observed at earlier stages, even though U-5 diet was interrupted from day 90 onwards, this fact pointing, again, to a sort of deferred effect of Ulva supplementation on colour parameters as well.

With regard to post-thawing cold storage of fillets, differences found in colour parameters were also significant as a result of Ulva supplementation, and such differences were consistently kept throughout the 10-d experimental period (Fig. 2). Roughly, in agreement with the findings already mentioned for fresh fish, all the modifications attributable to U-5 dietary treatment also pointed to improved colour parameters. Typically, during frozen storage of Senegalese sole takes place an undesirable effect characterized by the development of a reddish tone instead of the greenish-brown appearance of the skin, attributed to secondary metabolites resulting from lipid oxidation [22]. The richness of the genus Ulva in pigments such as chlorophylls and phycocyanines might have accounted for the reduction observed in the parameter $a^{*}$ in fish skin. On the other hand, high $b^{*}$ value in the skin is also a positive quality attribute resulting from Ulva supplementation, described not only in Senegalese sole, but also in tilapia [7], red porgy (Pagrus pagrus [59]) and channel catfish (Ictalurus punctatus [60]). The presence of xantophyls in this algal species might well have accounted for this effect [1].

Nevertheless, $U$. ohnoi was not able to modify any of the colour parameters measured in the blind side of Senegalese sole (data not shown), which can be explained by the lack of chromophores in this part of the body of adult fish [61]. This fact suggests that the pigments provided by Ulva are stored specifically in these specialized cells, responsible for the pigmentation of fish skin [62], instead of distributed non-specifically throughout other structures of the skin. Moreover, the fact that this phenomenon was observed not only at early stages of the feeding trial (in which fish were actually fed on the experimental diet), but also after $270 \mathrm{~d}$ (animals were fed with the control diet), suggests that the pigments are selectively retained in chromatophores over a sustained period of time.

On the other hand, the effects of Ulva supplementation on flesh colour were less evident, as deduced from the relatively scarce changes of $a^{*}$ and $b^{*}$ parameters compared to the skin side, and they are in agreement with those described by Valente et al. [7] for tilapia fed on Ulva-enriched finishing diets. Thus, increased lightness $\left(L^{*}\right)$ and decreased yellowness $\left(b^{*}\right)$, together with a lack of changes in $a^{*}$ parameter, were the main aspects affected by the dietary macroalgae. Given that, as mentioned, the dietary pigments are probably deposited principally in skin chromatophores [62], it was not expected that remarkable changes could happen in fish muscle owing to algal coloured compounds. Hence, it is unlikely that algal pigments were responsible for lower $b^{*}$ values observed in Ulva-fed fish up to $8 \mathrm{~d}$ of refrigerated storage, but rather the result of delayed lipid oxidation in these fillets (Fig. 1), as reported in previous studies [63,64].

Similarly, increased $L^{*}$ in muscle could be attributed to higher WHC of U-5 fillets compared to control batch, as also described previously $[5,64]$. It is well known that changes in muscle WHC reflect the integrity of muscle protein, responsible for retaining water molecules through electrostatic interactions, and thus, values for this parameter decrease during cold storage (Fig. 3) in parallel with the autolysis of muscle protein fractions due to endogenous proteases. From the point of view of consumer's acceptance, this parameter enables the organoleptic estimation of the dryness or juiciness of fish fillets [65].

In this context, protein hydrolysis (both of the myofibrillar and collagen fractions, $[66,67]$ ) accounts for changes in the textural parameters estimated by TPA analysis, among which the most relevant, in terms of its influence on purchase decision, is hardness. This parameter was influenced by U-5 diet (Table 5) during post-thawing cold storage, roughly in the sense that those fillets from fish fed with the Ulva-supplemented feed showed higher values. Scarce literature has been accessed in which the influence of dietary macroalgae on texture parameters has been assessed. Moroney et al. [5] reported no adverse impacts of red seaweed supplementation on salmon fillet textural parameters. Although no direct effects of algal compounds on the control of muscle protein disintegration have been described, nevertheless, it has long been known that the alteration of lipids taking place during frozen storage [68], not least the release of free fatty acids, might contribute to protein denaturation $[69,70]$. In agreement with this hypothesis, in this research fish fed with U-5 diet yielded not only improved fillet hardness (Table 5) and WHC (Fig. 3), but also lower lipid oxidation (Fig. 1). In addition, the lower lipid content in U-5 fish might also have accounted for higher firmness.

In the present state of knowledge, and besides the factors mentioned above, it is safe to say that the intimate mechanisms involved in the delay of firmness loss observed remain to be ascertained. Although the physiological changes underlying the observed effects on fish fillet quality parameters are virtually unknown, it has been profusely reported that modifications in the characteristics of feeds are readily reflected in the composition of fish, especially with regard to the lipid fraction [31,71,72]. Moreover, recent studies [39] have reported that Ulva biomass at low inclusion level caused beneficial effects on the relative expression of genes involved in the lipid and protein metabolism of Solea senegalensis. Perhaps this fact might have been involved in some of the effects observed in this study, not only at early stages of the feeding trial (up to $90 \mathrm{~d}$ ), but more interestingly, after interrupting the macroalgae supplementation as well. However, much additional information will be required before a complete understanding.

Finally, and by way of conclusion, any on-farm feeding strategy aimed at modifying fish quality attributes implies considerable economic costs, given that the specific functional ingredients should be added usually at the end of the productive cycle, this is, included in finishing diets. At this stage, the amount of feed required to finishing fish is considerably high, so that it is possible that the cost of the ingredients might outweigh the beneficial impact brought about on fish quality. Under this perspective, the deferred effects suggested by this study on Senegalese sole due to Ulva supplementation might well result of practical interest from an economical standpoint, given that this early-stage feeding strategy on juvenile fish seems to yield further valuable characteristics in commercial size fish.

Further additional studies aimed at assessing the potential longterm effects of macro and microalgae included in diets for aquacultured fish are required in order to fully ascertain the findings observed in this study.

\section{Statement of informed consent, human/animal rights}

The authors state that no conflicts, informed consent, human or animal rights are applicable. All studies involving fish were conducted in accordance with the requirements of the Directive 2010/63/EU, and the Spanish legislation (Real Decreto 53/2013), regarding the ethical rules applicable in research involving laboratory animals. Thereby, all 
the procedures were authorized by the Bioethics and Animal Welfare Committee of IFAPA (Junta de Andalucía, Spain).

\section{CRediT authorship contribution statement}

M.I. Sáez:Investigation, Formal analysis, Data curation, Writing original draft.A. Vizcaíno:Formal analysis.A. Galafat:Investigation, Formal analysis.V. Anguís:Investigation, Resources.C. Fernández-Díaz:Investigation, Resources.M.C. Balebona:Methodology.F.J. Alarcón:Resources, Data curation, Writing - original draft, Methodology.T.F. Martínez:Data curation, Writing - original draft, Methodology.

\section{Declaration of competing interest}

The authors declare that they have no known competing financial interests or personal relationships that could have appeared to influence the work reported in this paper.

\section{Acknowledgements}

This work was supported by INIA projects RTA2014-00023-C02-02 and RTA2014-00023-C02-01, and the European Regional Development Fund (ERFD). The MCYT project RTI2018-096625-B-C31 is also acknowledged for the financial funding. A.J. Vizcaíno was the recipient of a postdoctoral contract within the project SABANA (grant \# 727874) from the European Union's Horizon 2020 Research and Innovation program.

\section{References}

[1] A.H. Wan, S.J. Davies, A. Soler-Vila, R. Fitzgerald, M.P. Johnson, Macroalgae as a sustainable aquafeed ingredient, Rev. Aquacult. 11 (2018) 1-35.

[2] E.A. Wassef, A.F.M. El-Sayed, E.M. Sakr, Pterocladia (Rhodophyta) and Ulva (Chlorophyta) as feed supplements for European seabass, Dicentrarchus labrax L. fry, J. Appl. Phycol. 25 (2013) 1369-1376.

[3] G. Marinho, C. Nunes, I. Sousa-Pinto, R. Pereira, P. Rema, L.M.P. Valente, The IMTA-cultivated Chlorophyta Ulva spp. as a sustainable ingredient in Nile tilapia (Oreochromis niloticus) diets, J. Appl. Phycol. 25 (2013) 1359-1367.

[4] P. Rama Nisha, A. Elezabeth Mary, M. Uthayasiva, S. Arularasan, Seaweed Ulva reticulata a potential feed supplement in goldfish (Carassius auratus), J. Aquac. Res. Develop. 5 (2014) 5.

[5] N.C. Moroney, A.H. Wan, A. Soler-Vila, R. Fitzgerald, M.P. Johnson, J.P. Kerry, Inclusion of Palmaria palmata (red seaweed) in Atlantic salmon diets: effects on the quality, shelf-life parameters and sensory properties of fresh and cooked salmon fillets, J. Sci. Food Agri. 95 (2015) 897-905.

[6] N.C. Moroney, A.H. Wan, A. Soler-Vila, M.N. O'Grady, R.D. FitzGerald, M.P. Johnson, J.P. Kerry, Influence of green seaweed (Ulva rigida) supplementation on the quality and shelf life of Atlantic salmon fillets, J. Aquat. Food Prod. Technol. 26 (2017) 1175-1188.

[7] L.M.P. Valente, M. Araujo, S. Batista, M.J. Peixoto, I. Sousa-Pinto, V. Brotas, L.M. Cunha, P. Rema, Carotenoid deposition, flesh quality and immunological response of Nile tilapia fed increasing levels of IMTA-cultivated Ulva spp, J. Appl. Phycol. 28 (2016) 691-701.

[8] S. Gupta, N. Abu-Ghannam, Recent developments in the application of seaweeds or seaweed extracts as a means for enhancing the safety and quality attributes of foods, Innov. Food Sci. Emerg. Technol. 12 (2011) 600-609.

[9] S. Roohinejad, M. Koubaa, F.J. Barba, S. Saljoughian, M. Amid, R. Greiner, Application of seaweeds to develop new food products with enhanced shelf-life, quality and health-related beneficial properties, Food Res. Int. 99 (2017) 1066-1083.

[10] M. Araújo, P. Rema, I. Sousa-Pinto, L.M. Cunha, M.J. Peixoto, M.A. Pires, F. Seixas, V. Brotas, C. Beltrán, L.M.P. Valente, Dietary inclusion of IMTA-cultivated Gracilaria vermiculophylla in rainbow trout (Oncorhynchus mykiss) diets: effects on growth, intestinal morphology, tissue pigmentation, and immunological response, J. Appl. Phycol. 28 (2016) 679-689.

[11] S.L. Holdt, S. Kraan, Bioactive compounds in seaweed: functional food applications and legislation, J. Appl. Phycol. 23 (2011) 543-597.

[12] D.B. Stengel, S. Connan, Z.A. Popper, Algal chemodiversity and bioactivity: sources of natural variability and implications for commercial application, Biotech. Adv. 29 (2011) 483-501.

[13] B. Güroy, S. Cirik, D. Güroy, F. Sanver, A.A. Tekinay, Effects of Ulva rigida or Cystoseira barbata meals as a feed additive on growth performance, feed utilization, and body composition in Nile tilapia, Oreochromis niloticus, Turk. J. Vet. Anim. Sci. 31 (2007) 91-97.

[14] S. Ergün, M. Soyutürk, B. Güroy, D. Güroy, D. Merrifield, Influence of Ulva meal on growth, feed utilization, and body composition of juvenile Nile tilapia (Oreochromis niloticus) at two levels of dietary lipid, Aquacult. Int. 17 (2009) 355-361.

[15] E.M. Cabral, T.J.R. Fernandes, S.D. Campo, M. Castro-Cunha, M.B.P.P. Oliveira, M.L. Cunha, L.M.P. Valente, Replacement of fish meal by plant protein sources up to $75 \%$ induces good growth performance without affecting flesh quality in ongrowing Senegalese sole, Aquaculture 380-383 (2013) 130-138.

[16] R.W. Hardy, C. Lee, Aquaculture feed and seafood quality, Bull. Fish. Res. Agency 31 (2010) 43-50.

[17] J. Matos, C. Cardonoso, N. Bandarra, C. Afonso, Microalgae as healthy ingredients for functional food: a review, Food Funct. 8 (2017) 2672-2685.

[18] FAO, 2016. Planning for aquaculture diversification: the importance of climate change and other drivers. FAO Technical Workshop, Rome Italy, 2016.

[19] G. Hyldig, J. Nielsen, C. Jacobsen, H.H. Nielsen, Sensory and quality properties of packaged seafood, in: J.P. Kerry (Ed.), Advances in Meat, Poultry and Seafood Packaging, Woodhead Publishing, 2012, pp. 154-170.

[20] G. Cappeln, J. Nielsen, F. Jessen, Fatty acid and biochemical changes in mackerel (Scomberomorus commerson) and shark (Carcharhinus dussumieri) fillets during frozen storage, Amer-Eur. J. Sustain. Agric. 79 (1999) 1099-1104.

[21] J. Nielsen, F. Jessen, Quality of frozen fish, in: L.M.L. Nollet (Ed.), Handbook of Meat, Poultry and Seafood Quality, Blackwell Publishing, Iowa, USA, 2007, pp. $577-586$.

[22] A.C. Gonçalves, S.E. Antas, M.L. Nunes, Freshness and quality criteria of iced farmed senegalese sole (Solea senegalensis), J Agri. Food Chem. 55 (2007) 3452-3461.

[23] R.R.L. Guillard, Culture of phytoplankton for feeding marine invertebrates, in: W.L. Smith, M.H. Chanley (Eds.), Culture of Marine Invertebrate Animals, Plenum Press, New York, USA, 1975, pp. 26-60.

[24] AOAC, Official Methods of Analysis, Association of Official Analytical Chemists, USA, 2002

[25] J. Folch, M. Lee, G.H. Sloane Stanley, A simple method for the isolation and purification of total lipids from animal tissues, J. Biol. Chem. 226 (1957) 497-509.

[26] J. Rodríguez-Ruiz, E.H. Belarbi, J.L. García, D. López, Rapid simultaneous lipid extraction and transesterification for fatty acid analyses, Biotechnol. Tech. 12 (1998) 689-691.

[27] G. Lepage, C.C. Roy, Improved recovery of fatty acid through direct transesterification without prior extraction or purification, J. Lipid Res. 25 (1984) 1391-1396.

[28] L. Senso, M.D. Suarez, T. Ruiz-Cara, M. Garcia-Gallego, The possible effects of harvesting season and chilled storage on the fatty acid profile of the fillet of farmed gilthead sea bream (Sparus aurata), Food Chem. 101 (2007) 298-307.

[29] J. Buege, S. S. Aust, Microsomal lipid peroxidation, Methods Enzymol. 52 (1978) 302-310.

[30] CIE, Commission Internationale de l'Eclairage, Recommendations on uniform color spaces, color difference equations, psychometric color terms, Colorimetry, Bureau Central de la CIE, Paris, France, 1976.

[31] M.D. Suárez, T.F. Martinez, M.I. Sáez, A.E. Morales, M. García-Gallego, Effects of dietary restriction on post-mortem changes in white muscle of sea bream (Sparus aurata), Aquaculture 307 (2010) 49-55.

[32] M.C. Bourne, Texture profile analysis, Food Tech 32 (1978) 62-72.

[33] L.M.P. Valente, A. Gouveia, P. Rema, J. Matos, E.F. Gomes, I.S. Pinto, Evaluation of three seaweeds Gracilaria bursa-pastoris, Ulva rigida and Gracilaria cornea as dietary ingredients in European sea bass (Dicentrarchus labrax) juveniles, Aquaculture 252 (2006) 85-91.

[34] A.J. Vizcaíno, S.I. Mendes, J.L. Varela, I. Ruiz-Jarabo, R. Rico, F.L. Figueroa, R. Abdala, M.A. Moríñigo, J.M. Mancera, F.J. Alarcón, Growth, tissue metabolites and digestive functionality in Sparus aurata juveniles fed different levels of macroalgae, Gracilaria cornea and Ulva rigida, Aquac. Res. 4 (2015) 3224-3238.

[35] B. Jones, R. Smullen, A.G. Cartona, Flavour enhancement of freshwater farmed barramundi (Lates calcarifer), through dietary enrichment with cultivated sea lettuce, Ulva ohnoi, Aquaculture 454 (2016) 192-198.

[36] O. Yildirim, S. Ergün, S. Yamam, A. Tuker A, Effect of two seaweeds (Ulva lactuca and Enteromorpha linza) as a feed additive in diets on growth performance, feed utilization, and body composition of rainbow trout (Oncorhynchus mykiss), Kafkas Üniv. Vet. Fak Ültesi Dergisi 15 (2009) 455-460.

[37] J. Ortiz, N. Romero, P. Robert, Dietary fiber, amino acid, fatty acid and tocopherol contents of the edible seaweeds Ulva lactuca and Durvillaea antarctica, Food Chem. 99 (2006) 98-104.

[38] M.N. Garcıa Casal, A.C. Pereira, I. Leets, J. Ramırez, M.F. Quiroga, High iron content and bioavailability in humans from four species of marine algae, J. Nut. 137 (2007) 2691-2695.

[39] A.J. Vizcaíno, M. Fumanal, M.I. Sáez, T.F. Martínez, M.A. Moriñigo, C. FernándezDíaz, V. Anguis, M.C. Balebona, F.J. Alarcón, Evaluation of Ulva ohnoi as functiona dietary ingredient in juvenile Senegalese sole (Solea senegalensis): effects on the structure and functionality of the intestinal mucosa, Algal Res. 42 (2019) 101608.

[40] L. Parma, A. Badiani, A. Bonaldo, C. Viroli, F. Farabegoli, M. Silvia, E. Bonvini, M. Pirini, P.P. Gatta, Farmed and wild common sole (Solea solea L.): comparative assessment of morphometric parameters, processing yields, selected nutritional traits and sensory profile, Aquaculture 502 (2019) 63-71.

[41] K. Grigorakis, M.N. Alexis, A. Taylor, M. Hole, Comparison of wild and cultured gilthead sea bream, (Sparus aurata): composition appearance and seasonal variations, Int. J. Food Sci. Tech. 37 (2002) 1-8.

[42] S. Morais, L. Narciso, E. Dores, P. Pousão-Ferreira, Lipid enrichment for Senegalese sole (Solea senegalensis) larvae: effect on larval growth, survival and fatty acid profile, Aquacult. Int. 12 (2004) 281-298.

[43] M. Yildiz, E. Şener, M. Timur, Effects of differences in diet and seasonal changes on the fatty acid composition in fillets from farmed and wild sea bream (Sparus aurata, 
L) and sea bass (Dicentrarchus labrax, L), Int. J. Food Sci. Tech. 43 (2007) 853-858.

[44] K. Grigorakis, Compositional and organoleptic quality of farmed and wild gilthead sea bream (Sparus aurata) and sea bass (Dicentrarchus labrax) and factors affecting it: a review, Aquaculture 272 (2007) 55-75.

[45] B. Güroy, S. Ergün, D.L. Merrifield, D. Güroy, Effect of autoclaved Ulva meal on growth performance, nutrient utilization and fatty acid profile of rainbow trout, Oncorhynchus mykiss, Aquacult. Int. 21 (2013) 605-615.

[46] P. Dantagnan, A. Hernandez, A. Borquez, A. Mansilla, Inclusion of macroalgae meal (Macrocystis pyrifera) as feed ingredient for rainbow trout (Oncorhynchus mykiss): effect on flesh fatty acid composition, Aquac. Res. 41 (2009) 87-94.

[47] F. Norambuena, K. Hermon, V. Skrzypczyk, J.A. Emery, Y. Sharon, A. Beard, G.M. Turchini, Algae in fish feed: performances and fatty acid metabolism in Juvenile Atlantic Salmon, PLoS One 10 (2015) e0124042.

[48] M.S. Azaza, F. Mensi, J. Ksouri, M.N. Dhraief, B. Brini, A. Abdelmouleh, M.M. Kraïem, Growth of Nile tilapia (Oreochromis niloticus L) fed with diets containing graded levels of green algae Ulva meal (Ulva rigida) reared in geothermal waters of southern Tunisia, J. Appl. Ichthyol. 24 (2008) 202-207.

[49] S. Ergün, M. Soyuturk, B. Güroy, D. Güroy, D.L. Merrifield, Influence of Ulva meal on growth, feed utilization and body composition of juvenile Nile tilapia (Oreochromis niloticus) at two levels of dietary lipid, Aquac. Int. 17 (2008) 355-361.

[50] P. Burtin, Nutritional value of seaweeds, EJEAFChe 2 (2003) 498-503.

[51] S.L. Holdt, S. Kraan, Bioactive compounds in seaweed: functional food applications and legislation, J. Appl. Phycol. 23 (2011) 543-597.

[52] G. Yildiz, S. Celikler, O. Vatan, S. Dere, Determination of the anti-oxidative capacity and bioactive compounds in green seaweed Ulva rigida C. Agardh, Int. J. Food Prop. 15 (2011) 1182-1189.

[53] R. Pangestuti, S.K. Kim, Biological activities and health benefit effects of natural pigments derived from marine algae, J. Funct. Foods 3 (2011) 255-266.

[54] H.H.A. El Baky, F.K. El Baz, G. El Baroty, Evaluation of marine alga Ulva lactuca L. as a source of natural preservative ingredient, Int. J. Food Sci. Tech. 44 (2009) 1688-1695.

[55] L.S. Costa, G.P. Fidelis, S.L. Cordeiro, R.M. Oliveira, D.A. Sabry, R.B.G. Câmara, L.T.D.B. Nobre, M.S.S.P. Costa, J. Almeida-Lima, E.H.C. Farias, E.L. Leite, H.A.O. Rocha, Biological activities of sulfated polysaccharides from tropical seaweeds, Biomed. Pharmacother. 64 (2010) 21-28.

[56] Ö. Ozden, N. Erkan, Effect of different packaging methods on the shelf-life of marinated rainbow trout, Arch. Leb. 57 (2006) 69-75.

[57] K.M. Sefc, A.C. Brown, E.D. Clotfelterb, Carotenoid-based coloration in cichlid fishes, Comp. Biochem. Physiol. Mol. Integr. Physiol. 173 (2014) 42-51.

[58] L. Tacchi, R. Bickerdike, A. Douglas, C.J. Secombes, S.A.M. Martin, Transcriptomic responses to functional feeds in Atlantic salmon (Salmo salar), Fish Shellfish Immunol 31 (2011) 704-715.

[59] C.T. Kalinowski, L.E. Robaina, H. Fernández-Palacios, D. Schuchardt, M.S. Izquierdo, Effect of different carotenoid sources and their dietary levels on red porgy (Pagrus pagrus) growth and skin colour, Aquaculture 244 (2005) 223-231.
[60] M.H. Li, E.H. Robinson, D.F. Oberle, P.V. Zimba, Effects of various dietary carotenoid pigments on fillet appearance and pigment absorption in channel catfish, Ictalurus punctatus, J. World Aquac. Soc. 38 (2007) 557-563.

[61] P.I.S. Pinto, C.C. Guerreiro, R.A. Costa, J.F. Martinez-Blanch, C. Carballo, F.M. Codoñer, M. Manchado, D.M. Power, Understanding pseudo-albinism in sole (Solea senegalensis): a transcriptomics and metagenomics approach, Sci. Reports 9 (2019) 13604.

[62] R. Fujii, The regulation of motile activity in fish chromatophores, Pigment Cell Res. 13 (2000) 300-319.

[63] A. Thanonkaew, S. Benjakul, W. Visessanguan, E.A. Decker, Development of yellow pigmentation in squid (Loligo peali) as a result of lipid oxidation, J. Agric. Food Chem. 54 (2006) 956-962.

[64] M.I. Sáez, T.F. Martínez, S. Cárdenas, M.D. Suarez, Effect of different preservation strategies on microbiological counts, lipid oxidation and colour of cultured meagre (Argyrosomus regius, L) fillets, J. Food Process. Preserv. 39 (2015) 768-775.

[65] A.S. Duun, T. Rustad, Quality changes during superchilled storage of cod (Gadus morhua) fillets, Food Chem. 105 (2007) 1067-1075.

[66] C. Delbarre-Ladrat, R. Cheret, R. Taylor, V. Verrez-Bagnis, Trends in post mortem aging in fish: understanding of proteolysis and disorganization of the myofibrillar structure, Crit. Rev. Food Sci. Nutr. 46 (2006) 409-421.

[67] M. Ando, Y. Yoshimoto, K. Inabu, T. Nakagawa, Y. Makimodan, Post-mortem change of three-dimensional structure of collagen fibrillar network in fish muscle pericellular connective tissues corresponding to post-mortem tenderization, Fisheries Sci 61 (1995) 327-330.

[68] A. de Koning, T. Mol, Quantitative quality tests for frozen fish: soluble protein and free fatty acid content as quality criteria for hake (Merluccius capensis) stored at $-18^{\circ} \mathrm{C}$, J. Sci. Food Agric. 58 (1991) 449-458.

[69] I.M. Mackie, The effects of freezing on flesh proteins, J. Food Rev. Int. 9 (1993) 575-610.

[70] C.G. Sotelo, C. Piñeiro, R.I. Pérez-Martín, Denaturation of fish proteins during frozen storage: role of formaldehyde, Z. Lebensm. Unters. Forsch. 200 (1995) $14-23$.

[71] C. Regost, J. Arzel, M. Cardinal, J. Robin, M. Laroche, S.J. Kaushik, Dietary lipid level, hepatic lipogenesis and flesh quality in turbot (Psetta maxima), Aquaculture 193 (2001) 291-309.

[72] M.I. Sáez, G. Navarro, S. García-Mesa, T.F. Martínez, M. García-Gallego, M.D. Suárez, Influence of pre-slaughtering feed restriction on muscle characteristics of farmed sea bass (Dicentrarchus labrax L.) during cold storage, J. Sci. Food Agric. 93 (2013) 2323-2330.

[73] A.J. Vizcaíno, A. Rodiles, G. López, M.I. Sáez, M. Herrera, I. Hachero, T.F. Martínez M.C. Cerón-García, F.J. Alarcón, Growth performance, body composition, and digestive functionality of Senegalese sole (Solea senegalensis Kaup, 1858) juveniles fed diets including microalgae freeze-dried biomass, Fish Physiol. Biochem. 44 (2018) 661-677. 